H. 455

LA-7162

AFATL-TR-78-8
UC-11

Issued: July 1978

\title{
Further Studies of Long-Term Ecological Effects of Exposure to Uranium
}

Vame C. Harson

Felix R Miera, Jr. Environmental Science Gropp (H-12)

$\frac{\sigma}{5}$

¿

$\frac{7}{\omega}$

离

$\stackrel{2}{\frac{2}{5}}$

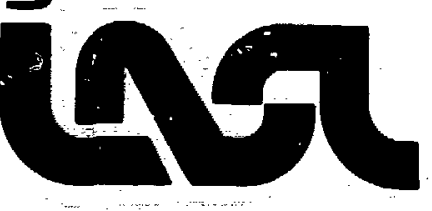


SECURITY CLESSIFICATION OF THIS PAGE (mon Date Enturmd

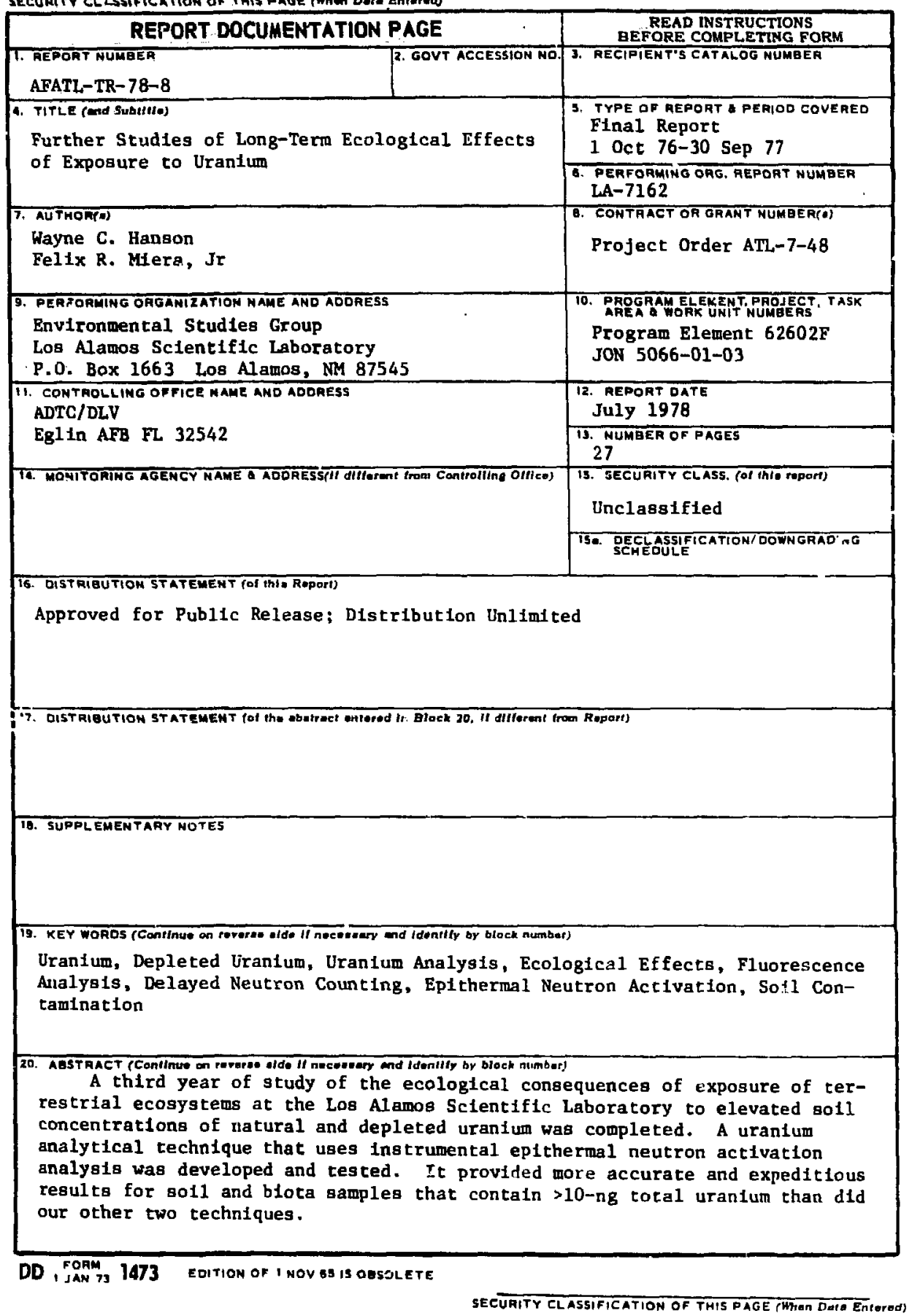


SECUniTY CLASSIFICATION OF THIS PAOECMmen Deta Bntorvd)

20. ABSTRACT

Spatlal varlability in sampling for soti uranium distribution by a polar coordinate system was evaluated in randomly selected soll cores. Varlactons for surface ( 0 - to 2.5-cm-deep) solls vere 0.18 at 10 m from the detonation point and 0.96 at $50 \mathrm{~m}$. Results were strongly influenced by past uranium dispersal patterns, vartable leaching of urantum debris, and surface water runoff.

A tocal surface (0- to $5-\mathrm{cm})$ soll urantum inventory within a 12.6-ha circle centered on the E-F detonation point was estimated to be $3000 \mathrm{~kg}$ when calculated by soll urantum concentration isopleths and $4500 \mathrm{~kg}$ when using annuli of a polar coordinate sampling system.

Urantum concentrations in tissues of deer mice (Peromyscus maniculatug) and pocket gophers (Thomomy bottae) were sufficlently different to conciude that the greater bioavallability of uranium in the top fer millimeters of soll at E-F Site, combined with the difference in grooming and food habits of the animals, resulted in greater contamination of deer wise than of pocket gophers.

Invertebrace populations Inhabiting areas of high and wedim soll urantum concentrations at LASL sites were sampled by pitfall trapping and insect net sweeps. There was no conclusive evidence of a differenclal population response to areas of relatively high uranium concentrations and to control areas.

SECURITY GLASSIFICA TION OF THIS PAGE(When Date Entered) 
CONTEN'S

ABSTRACT . . . . . . . . . . . . . . . . . . . . . 1

I. INTRODUCTION . . . . . . . . . . . . . . . . . . . . 2

II. METHODS , . . . . . . . . . . . . . . . . . . . . . 2

A. Analytical Procedures Development for Determination of Uranium in Soils . . . . . . . 2

B. Determination of Uranium in EAFB Soils..... 3

C. Inventory Estimate and Distribution of Uranium in LASL E-F Site Soils............. . 3

D. Uranium Determinations in Small Mammal Samples. 5

E. Macrofauna Sampled at LASL Study Sites.....5 5

III. RESULTS . . . . . . . . . . . . . . . . . . . . 5

A. Analytical Procedures Development . . . . . . 5

B. Uranium Concentrations in EAFB Soils . . . . . . 6

C. Soil Uranium Distribution at LASL E-F Site . . . 7

1. Spatial Variability in Sampling for Uranium Dlstribution . . . . . . . . . . . . 7

2. Uranium in Soil Separates . . . . . . . 7

3. Uranium Inventory Estimates by Annuli and Isopleth Methods... . . . . . . . . . . 10

D. Bagnold Collection of Redistributed Uranium particles . . . ............ . 12

E. Uranium Concentrations in Small-Mammal Tissues . 13

F. Macrofauna Studies . . . . . . . . . . . 15

1. Numbers of Individuals and Species Taken by Various Collection Methods . . . . . . . 15

2. Distributions of the Major Invertebrate Orders . . . . . . . . . . . . . . . . . . 15

a. Acarina (?icks and Mites). . . . . . . 16

b. Araneida (Spiders) . . . . . . . . . . 17

c. Collembola (Springtails) . . . . . 18

d. Hymenoptera (Ants and Wasps) . . . . . . 18

e. Hemiptera (Homoptera and Heteroptera) (Bugs) . . . . . . . . . . . . . . . . . 18

f. Thysanoptera (Thrips). . . . . . . 18

g. Diptera (Flies) . . . . . . . . . 18

h. Coleoptera (Beetles). . . . . . . . . 18

3. Population Responses to Uranium . . . . , 18 
IV. SUMMARY AND CONCLUSIONS . . . . . . . . . . . . . . . 19

ACKNOWLEDGMENTS . . . . . . . . . . . . . . . . . . 20

REFERENCES . . . . . . . . . . . . . . . . . . . . . . . . 20

APPENDIX . . . . . . . . . . . . . . . . . . . . . . . . . . 22

DISTRIBUTION LIST . . . . . . . . . . . . . . , . 27 


\section{FURTHER STUDIES OF LONG-TERM ECOLOGICAL} EFFECTS OF EXPOSURE TO URANIUM

by

Wayne C. Hanson and Felix R. Miera, Jr.

\section{ABSTRACT}

A third year of study of the ecological consequences of exposure of terrestrial ecosystems at the Los Alamos Scientific Laboratory to elevated soil concentrations of natural and depleted uranium was completed. A uranium analytical technique that uses instrumental epithermal neutron activation analysis was developed and tested. It provided more accurate and expeditious results for soil and biota samples that contain $>10-n g$ total uranium than did our other two techniques.

Spatial variability in sampling for soll uranium distribution by a polar coordinate system was evaluated in randomly selected soil cores. Variations for surface ( 0 - to $2.5-\mathrm{cm}$-deep) soils were 0.18 at $10 \mathrm{~m}$ from the detonation point and 0.96 at $50 \mathrm{~m}$. Results were strongly influenced by past uranium dispersal patterns, variable leaching of uranium debris, and surface water runoff.

A total surface $(0-$ to $5-\mathrm{cm})$ soil uranium inventory within a $\mathbf{1 2 . 6 - h a}$ circle centered on the E-F detonation point was estimated to be $3000 \mathrm{~kg}$ when calculated by soil uranium concentration isopleths and $4500 \mathrm{~kg}$ when using annuli of a polar coordinate sampling system.

Uranium concentrations in tissues of de:sr mice (Peromyscus maniculatus) an pocket gophers (Thomomys bottae) were sufficiently different to conclude that the-greater bioavailability of uranium in the top few millimeters of soil at E-F Site, combined with the difference in grooming and food habits of the animals, resulted in greater contamination of deer nilice than of pocket gophers.

Invertebrate populations inhabiting areas of high and medium soil uranium concentrations at LASL sites were sampled by pitfall trapping and insect net sweeps. There was no conclusive evidence of a differential population response to areas of relatively high uranium concentrations and to control areas.

\footnotetext{
This tepurt was prepared as an actumi of work This reped the United Staies Government. Neither Ule United States nor the United Siates Depastment of Energy, nut any of their employees, nor any nf their contractors, subeonssactors, or their employees. makes contractor, a express or implied, or assumes any legal

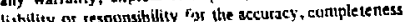

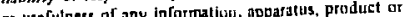

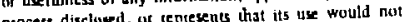
parcess disclused, ar cenesents thingely owned rights.
} 


\section{INTRODUCTION}

This report summarizes research from October 1, 1976, through September 30, 1977, on the ecological effects of exposure to uranium. Included are (1) a comparison of three different analytical techniques employed for uranium determinations; (2) analytical results from three sets of soil samples from test ranges at Eglin Air Force Base (EAFB), Florida; (3) an inventory estimate for uranium in the top $5 \mathrm{~cm}$ of soil from a 12.6-ha circle as well as the distribution of uranium in soil size fractions at the Los Alamos Scientific Laboratory (LASL) E-F Site; and (4) biotic responses to the chemical toxicity of environmental uranium.

The greneral scope and objectives of this study and the site descriptions were presented in the 1976 and 1977 completion reports. 1,2 Objectives of the research efforts reported here were:

(1) To describe the spatial variations of uranium concentrations in soil at E-F Site as functions of the soil depth and distance from the detonation point;

(2) To determine the distribution of uranium in soil size fractions as a function of soil depth and distance from the detonation point at E-F Site;

(3) To estimate the uranium inventory within a $200-m$ radius of the $E-F$ detonation point in the $0-$ to 5 -cm horizon;

(4) To examine the poteitial for redistribution of uranium from this site by creep and saltation; and

(5) To evaluate the responses of soil and vegetative invertebrates to uranium chemical toxicity at LASL sites.

These data have application to field situations at both EAFB and LASL, where substantial amounts of uranium have been expended in weapons testing programs.

I I . METHODS

A. Analytical Procedures Development for Determination of Uranium in Soils

Rapid analysis for uraniun in various matrices has become increasingly important with the advent of the energy crisis. The need for appreciable production of uranium to supply the nuclear facilities that offer alternatives to fossil fuel power plants has prompted hydrogeochemical survey programs to discover subsurface ore bodies in several countries. ${ }^{3-6}$ Decontamination of areas in which radioactive materials have been stored or discharged usually involves uranium, though the chemical toxicity aspects of that element are often more important than radiological considerations. Such is the case in the military testing of depleted-uranium $\left({ }^{235} \mathrm{U} /{ }^{238} \mathrm{U}<0.0072\right)$ penetrators at EAFB, where varying amounts of uranium are expended over test ranges that receive appreciable rainfall ( $\left.155 \mathrm{~cm} / \mathrm{yr}^{2}\right)$. Ecological consequences of uranium in the environment then are magnified because of weathering of uranium fragments and increased mobility of uranium in drainage areas.

The need for prompt definition of uranium concentrations in EAFB soils to monitor the movement of uranium and for a more expeditious means of processing appreciable LASL samples motivated our chemists to investigate and compare three uranium analytical techniques. 7 Fluorescence analysis (FA) ${ }^{8}$ was used for al1 previous 1 y reported uranium determinations but requires that the sample be dissolved in $\mathrm{HNO}_{3} / \mathrm{HF}$ mixture and retained in solution. FA is also very sensitive to quenching interferences and to exact conditions during pellet fusion and may occasionally exhibit poor precision. Thermal-neutron-induced delayed neutron counting (DNC) ${ }^{9}$ methods are based on the assumption of a fixed uranium isotopic ratio $\left({ }^{235} \mathrm{U} /{ }^{238} \mathrm{U}\right)$ because ${ }^{238} \mathrm{U}$ does nut participate in neutron production. If the ratio departs from 0.0072 (crustal abundance), large errors may occur in the determination of total uranium.

The availability of the pneumatic epithermal neutron facility at the LASL Oriaga West Reactor provided a unique capability to analyze soil samples by a third method, 
instrumental epithermal neutron activation analysis (IENAA). 10 Both the IENAA and DNC methods are nondestructive; thus the same sample aliquot could also be examined by FA. Two-gram aliquots of 33 soil samples were randomly selected from a set of EAFB samples submitted for uranium determination and subjected to IENAA, DNC, and finally FA.

In the IENAA analysis, samples were first irradiated with epithermal neutrons (energy range 280 to $1000 \mathrm{eV}$ ) for $2 \mathrm{~min}$. After 2 to 4 days' decay, the samples were counted for 5 min each on a large Ge(Li) detector ( $F W H M=1.9 \mathrm{keV}$ at $1332 \mathrm{keV}$ ). The 228- and 278-keV transitions from the decay of $239 \mathrm{~Np}$ (physical half-1ife 2.35 days) were observed and used for quantitative analysis. Spectra of gamma rays wore accumulated on pulse height analyzers, the regions of interest punched on paper tape, and the data reduced by electronic computer programs. International Atomic Energy Agency (IAEA) soils with certified uranium concentrations were used to standardize the analyses.

DNC measurements were performed on each sample by irradiating the sample for $20 \mathrm{~s}$ in a thermal-neutron flux. Irradiations were made at different reactor power levels, but in all cases, the thermal-neutron flux was monitored during the exposure by a $f$ ission ion chamber. The sample was pneumatically transferred to a neutron detector ${ }^{11}$ of $27 \%$ efficiency and counted for $20 \mathrm{~s}$ following a 10-s delay. The neutron data were normalized to a constant flux, and the system was calibrated to samples of VBS SRM-1933, a soil of standardized uranium concentration. Uranium concentrations were calculated with the assumption that the $235_{\mathrm{U}}$ abundance was normal.

In the FA method, soil samples were dissolved by standard techniques using acid digestion. Small volumes were pipetted onto 50-mg NaF/LiF pellets and fused for 2 min at $1200^{\circ} \mathrm{C}$ using a burner similar to that of price et al. ${ }^{2}$ The pellets were allowed to cool for $15 \mathrm{~min}$ and then the fluorescence at $245 \mathrm{~nm}$ was "read" on il fluorometer. The resulting data were reduced by computer to final concentrations. B. Determination of Uranium in EAFB Soils Sets of 83,63 , and 52 EAFB soil samples were received for uranium analyses at LASL as a part of EAFB range cleanup operations. The small size of the samples (20 g) prer?uded the usual grinding and homogenizing of the soil before aliquoting and analysis; therefore, $2-\mathrm{g}$ aliquots were directly processed by the IENAA technique.

A portion of the second set of simples was used for the comparison of the three uranium analytical techniques described in the previous section.

c. Inventory Estimate and Distribution of Uranium in LASL E-F Site Soils

The polar coordinate sampling system devised for determining the soil uranium inventory at the LASL E-F Site study area was described in the 1977 completion report. 2 Briefly, samples were taken at intersectio:s of radii that extended from the detonation point at each $45^{\circ}$ azimuth and concentric circles $10,20,30,40,50$, 75, 100,150 , and $200 \mathrm{~m}$ from the detonation point. A polyvinylchloride coring tube (2.5-cm-i.d.) was used to collect two $30-\mathrm{cm}-$ deep soil cores spaced $0.5 \mathrm{~m}$ apart at each sampling location, yielding 144 soil cores total. The cores were subdivided into six vertical segments, beginning at the lower end of the core to minimize cross-contaminition.

Thirty per cent of the duplicate cores collected from the NE, SE, SW, and NW quadrants were randomly selected for uranium analyses of whole samples to define the spatial variability of uranium with distance from the detonation point and with depth into the soil profile.

Forty randomly selected soil samples representing duplicate 0 - to 5 -cm- and 5to 10-cm-deep cores collected from the $\mathrm{N}$, $E, S$, and $W$ quadrants at distances of 10 , $20,50,100,150$, and $200 \mathrm{~m}$ from the detonation point were processed for soi] 
particle size analysis. They weie mechanically separated into six size fractions by a sonic sifter that yielded sample components of <53-um, 53- to 105- «m, 105- to $500-\mu \mathrm{m}, 500-$ to $1000-\mu \mathrm{m}, 1-$ to $2-\mathrm{mm}$, and 2to $23-\mathrm{mm}$ diamet:r. Small soil particles were blown from the larger soil separates with an air hose during sifting to minimize their carryover. The particle diameters may be further described according to US Department of Agriculture Soil Conservation Service standard soil size categories as follows.

\begin{tabular}{|c|c|}
\hline Particle Diam $(\mu \mathrm{m})$ & Size Fraction \\
\hline$<53$ & Silt and clay \\
\hline $53-105$ & Very fine sand \\
\hline $105-500$ & Medium and fine sand \\
\hline $500-1000$ & Coarse sand \\
\hline $1000-2000$ & Very coarse sand \\
\hline $2000-23000$ & Coarse fragments \\
\hline
\end{tabular}

Bagnold dust collectors (Fig. 1) were used to evaluate uranium particle movemen by saltation and creep. Two such instruments were placed at the E-F Site, one near the detonation point and the other approxjmately $40 \mathrm{~m} \mathrm{NE}$, in the downwind vector of prevailing winds. These instruments are designed to collect wind-suspended particles at six separate $15-\mathrm{cm}$ heights ranging from ground level (0 to $0.5 \mathrm{~cm}$ ) to $75 \mathrm{~cm}$ above the ground surface. Samples were collected at monthly intervals beginning in April 1977; however, it was necessary to composite the first 3 months' collections to provide sufficient mass for chemical analysis. All samples were separated into size fractions of $<100 \mu \mathrm{m}$ and $>100 \mu \mathrm{m}$ before uranium chemical analyses.

An estimate of the uranium inventory in surface (0- to 5-cm-deep) soil within tho 200-m-radius (12.6-ha) circle centered on the E-F Site detonation point was calculisted by two different methods, both of which bas lcally employed the same equations used in calculating the Potrillo Canyon uranium inventory reported last year. ${ }^{2}$ The first method consisted of calculating the surface area enclosed by an annulus at

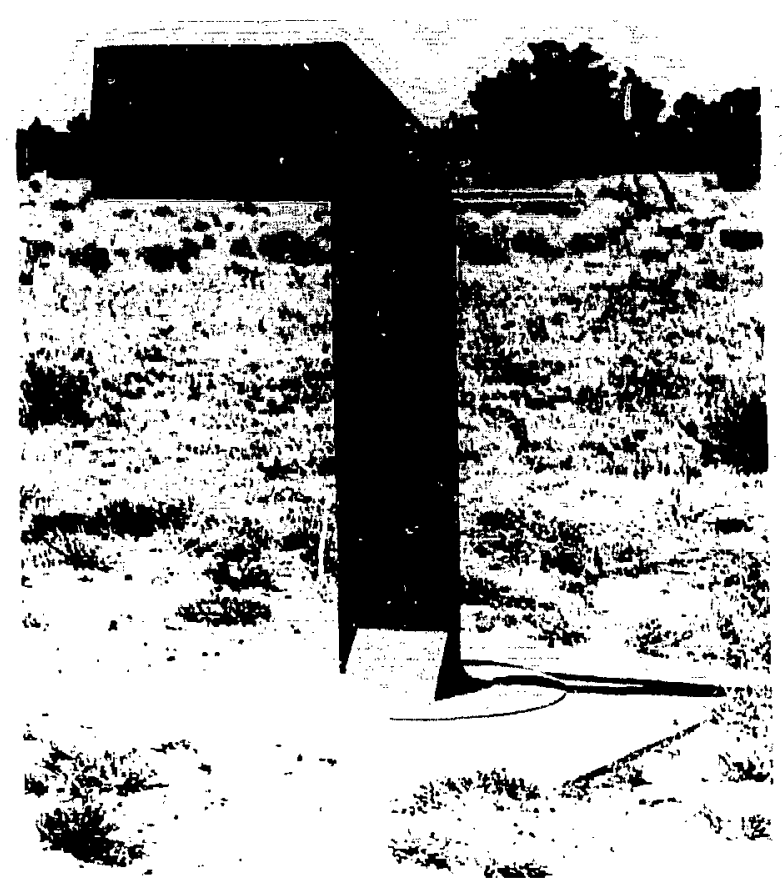

Fig. 1. Bagnold dust collector apparatus installed at field sampling locatiun. Collection ports are locaed along upwind (right) edge. Collection boxes are situated in base.

the midpoint between each sampling distance (that is, the surface area from 0 to $5 \mathrm{~m}$, 5 to $15 \mathrm{~m}$, etc.) and applying a median uranium concentration derived from all sampling points within each area.

The second method involved calculating the surface areas of $i$ ix soil uranium concentration isopleths ranging from $\lessdot 30$ to $>3000 \mu \mathrm{g} / \mathrm{g}$ and multiplying by the median uranium concentration for each isopleth. The surface soil uranium concentrations were log-transformed and the location data converted from polar coordinate values to Cartesian coordinate values. A plane surface was generated by an electronic data processing program that interpolated between data points to establish isopleths for six 
arbitrarily selected concentration gradients. In each method, the total uranium inventory was obtained by suming the values of the individual segments.

D. Uranium Determinations in Sma 11 Mammal Samples

Samples of two sympatric small mamnal species Peromyscus maniculatus (deer mouse) and Thomomys bottae (valley pocket gopher), were trapped at E-F Site during April and May 1977. Deer mice were taken by snap traps in lines parallel to the two earth mounds that bracket the detonation point, and pocket gophers were trapped at their mounds of freshly excavated dirt withis a radius of $100 \mathrm{~m}$ from the detonation point. The trapping was done over a 3-week period to preclude Immigration of transient animals. The animals were carefuliy dissected to minImize cross-contamination of internal organs and tissues by soil particles adhering to the fur.

Ashed $\left(450^{\circ} \mathrm{C}\right)$ samples of the pelt, gastrointestinal (GI) contents, lungs, liver, kidney's, and carcass (skeleton and muscle) were pooled from pairs of animals to provide sufficient mass for IENAA.

E. Macrofauna Sampled at LASL Study Sites

Studies of the invertebrate communities at E-F and Lower Slobovia (LS) Sites were continued to evaluate possible effects of exposure to elevated levels of uranium upon populations. Sampling was accomplished by (1) pitfall traps, to sample the wandering forest-floor invertebrates, and (2) insect sweep nets, to collect the invertebrates associated with the understory vegetation in areas of high and medium levels of uranium in soil. Samples we re collected at the same four locations from which soil cores were taken during 1975 and 1976 for extraction of soil- and litter-inhabiting invertebrates by Tullgren funnel techniques.

Five pitfall traps were installed at 10-m intervals along transects at $E-F$ and LS Sites and at each of their control sites. Each trap was made of a $1-\ell$ polyethylene bottle, the bottom of which was replaced by a funnel and apron that allowed it to be inverted and set flush with the ground surface within a permanently placed metal can. About $100 \mathrm{ml}$ of $70 \%$ ethyl alcohol was placed in each trap as a collecting and preserving medium. Collection periods of $72 \mathrm{~h}$ each were made during 1976, one in March, three in May, one in June, two in September, and one in November.

A standard insect net was used to obtain three 50-sweep samples through understory vegetation at each of the four study sites during November 1975 and February, March, May, September, and November 1976.

\section{RESULTS}

A. Analytical Procedures Development

Comparisons of uranium concentrations determined by IENAA, DNA, and FA are presented in Table $I$. With the exception of 6 samples, the DNA results were low compared to the values obtained by the other two methods. This was expected because DNA measures ${ }^{235} U$ and calculates a uranium concentration assuming normal isotopic abundince; these particular samples were EAFB soils slightly contaminated with depleted uranium rather than natural urarium, hence the low results.

With a few exceptions, the comparison of data obtained by IENAA and FA was very good, as shown in the ratio of the two sets of results. Deviations of this ratio from 1.0 indicate relative variations of the results. The mean of the ratio was $0.91 \pm$ 0.24 (std dev), or if the very low ratio obtained for Sample No. 1868 was excluded, the ratio was $0.94 \pm 0.19$ (std dev). A least squares fit of a line through these data points was $y=27.4+0.91 x$, with a coefficient of determination $\left(r^{2}\right)$ of 0.99 . This indicated a slightly lower but trivia? bias of the IENAA/FA ratio. Analysis of two standards also showed good agreement between the results obtained by IENAA, FA, and DNA and the certified value.

Considering these results, the significant reduction in cost and time, and the 
TABLE I

URANIUM CONCENTRATIONS IN 20-g SOIL ALIQUOTS

DETERMINED BY THREE TECHNIQUES

\begin{tabular}{|c|c|c|c|c|}
\hline Sample Nu! & $\begin{array}{l}\text { IENAA } \\
\text { (ppm) }\end{array}$ & $\begin{array}{r}\text { DNA } \\
\text { (ppm) } \\
\end{array}$ & $\begin{array}{c}\text { FA } \\
\text { (ppm) }\end{array}$ & IENAA/FA \\
\hline $\begin{array}{r}1651 \\
52 \\
60 \\
1707\end{array}$ & $\begin{array}{r}14500 \\
18800 \\
1500 \\
3,2\end{array}$ & $\begin{array}{r}4370 \\
5210 \\
654 \\
3.9\end{array}$ & $\begin{array}{r}14400 \\
21500 \\
1680 \\
4.5\end{array}$ & $\begin{array}{l}1.04 \\
0.87 \\
0.89 \\
0.71\end{array}$ \\
\hline $\begin{array}{l}08 \\
31 \\
33 \\
34 \\
30 \\
40 \\
47\end{array}$ & $\begin{array}{r}62 \\
4600 \\
2200 \\
3100 \\
600 \\
1440 \\
3.4\end{array}$ & $\begin{array}{r}59 \\
2020 \\
774 \\
1056 \\
375 \\
712 \\
3.7\end{array}$ & $\begin{array}{r}63 \\
5500 \\
2400 \\
3900 \\
620 \\
1700 \\
2.6\end{array}$ & $\begin{array}{l}0.98 \\
0.84 \\
0.92 \\
0.79 \\
0.97 \\
0.85 \\
1.31\end{array}$ \\
\hline $\begin{array}{l}48 \\
71 \\
72 \\
73 \\
74 \\
79 \\
80 \\
87\end{array}$ & $\begin{array}{r}29 \\
3400 \\
5300 \\
2000 \\
2200 \\
440 \\
1000 \\
2,2\end{array}$ & $\begin{array}{r}20 \\
1480 \\
2090 \\
678 \\
726 \\
255 \\
484 \\
4,0\end{array}$ & $\begin{array}{r}23 \\
3500 \\
6800 \\
2000 \\
2200 \\
500 \\
1400 \\
2.7\end{array}$ & $\begin{array}{l}1.27 \\
0.97 \\
0.78 \\
1.00 \\
1.00 \\
0.88 \\
0.71 \\
0.81\end{array}$ \\
\hline $\begin{array}{r}88 \\
1811 \\
12 \\
13 \\
14 \\
19 \\
27 \\
28\end{array}$ & $\begin{array}{r}26 \\
3100 \\
3600 \\
2700 \\
2900 \\
330 \\
1.3 \\
9.0\end{array}$ & $\begin{array}{r}19 \\
1280 \\
1200 \\
930 \\
790 \\
225 \\
3.9 \\
7.5\end{array}$ & $\begin{array}{r}22 \\
3000 \\
4200 \\
3300 \\
2600 \\
360 \\
3.1 \\
6.6\end{array}$ & $\begin{array}{l}1.18 \\
1.03 \\
0.86 \\
0.82 \\
1.11 \\
0.92 \\
0.58 \\
1.36\end{array}$ \\
\hline $\begin{array}{l}51 \\
52 \\
53 \\
54 \\
67 \\
68\end{array}$ & $\begin{array}{r}2200 \\
8200 \\
2200 \\
2200 \\
1.1 \\
1.1\end{array}$ & $\begin{array}{r}866 \\
4630 \\
823 \\
701 \\
3.7 \\
6.1\end{array}$ & $\begin{array}{c}2000 \\
8850 \\
2400 \\
2000 \\
2.4 \\
10\end{array}$ & $\begin{array}{l}1.10 \\
0.93 \\
0.92 \\
1.10 \\
0.46 \\
0.11\end{array}$ \\
\hline
\end{tabular}

$\begin{aligned} \bar{x} & =0.91 \\ s_{x} & =0.24\end{aligned}$

Standards

$\begin{array}{lcccl}\text { NBS } & 10.6 \pm 0.6 & 10.6 \pm 0.6 & 8.6 \pm 1.0 & (\text { Certifi,d Value }=11.6 \pm 0.2) \\ \text { IAEA } & 118 \pm 5 & 128 \pm 2 & 112 \pm 7 & (\text { Cerrifec Value }=119)\end{array}$

increased reliability, IENAA was selected as the method to be used in most future uranium analyses in our laboratory. The detection limit for both FA and IENAA is considered to be 10-ng total uranium; however, results from materials that contain less than $1.0 \mathrm{ppm}(=\mu \mathrm{g} / \mathrm{g})$ are considered to be highly variable. 7

\section{B. Uranium Concentrations in EAFB Soils} Analytical results for the three sets of EAFB soil samplt: are presented in the
Appendix as Tables A-I, A-II, and A-III. The samples were collected by EAFB personnel as a part, of test range cleanup operations or other activities and our interpretation is limited to the analytical parameters of the data.

The data in Table A-I are mosly nearbackground levels of uranium contained in 2-g aliquots taken from six soil samples, each collected to a depth of $5 \mathrm{~cm}$ at the various sampling points. The smal? aliquot 
masses precluded the soil sample grinding and homogenizing that usually precede our analyses and may have been a factor in creating greater variation in resuits than expected.

Table A-II presents uranium analytical results of samples taken from barrels of contaminated soil removed from EAFB test ranges by a contractor. Uranium concentrations ranged from 30 to $4900 \mathrm{ppm}$, and duplicate aliquots had Coefficients of Variation ( $\mathrm{CV}=$ standard deviation/mean) of 0 to 0.68 . Variability was usually greatest in samples that had uranium concentrations near the detection limit of $10 \mathrm{ng}$ total. Results presented in Table A-III are for samples taken in the same manner as those in Table $A-I$ and are generally simi1 ar.

C. Soil Uranium Distribution at LASL E-F Site

1. Spatial Variability in Sampling for Uranium Distribution. Our 1977 completion report discussed uranium distribution in E-F soils based on analyses of single samples taken at each sampling location. A "within sample" variability, due to sample processing and chemical analysis factors, was repo-tied to range from 0 to 0.12 . We now report data obtained from randomly selected duplicate samples, which were taken at locations $0.5 \mathrm{~m}$ from, and parallel to, those reported last year, so that we can determine the spatial variability occurring in our polar coordinate sampling.

CVs for surface (0- to $2.5-\mathrm{cm}$-deep) soils at various distances from the detonation point are shown in Table II. Values for sample pairs taken $0.5 \mathrm{~m}$ apart were lowest $(0.18)$ at the $10-m$ distance and greatest $(0.96)$ at $50 \mathrm{~m}$. The variation for individual sampling locations ranged from 0.04 to 1.06 and showed no consistent pattern related to distance from the origin of the uranium. These data illustrated the strong influence of the past programs at E-F Site upon uranium distribution patterns, particularly when all samples at a given distance from the detonation point were averaged. Greatest variation then occurred in samples $100 \mathrm{~m}$ or farther from the detonation point, reflecting the frequent inclusion of samples that contained large uranium particles and those that contained little or no ura:ium above background levels.

Uranium concentrations in various depth increments of duplicate $30-\mathrm{cm}$ soll cores taken $0.5 \mathrm{~m}$ apart at E-F Site (Table III) showed a trend toward grenter variability among samples of the deeper (>10-cm) horizons. Values were between 0.44 and 0.57 in the depths to $10 \mathrm{~cm}$ and between 0.71 to 0.94 in soil from 10 to $30 \mathrm{~cm}$ below the surface.

These data suggest that results from the soil sampling are probably influenced by the variable deposition of uranium debris from past explosive tests (fragments from 2 ins to several centimeters in diameter), by the subsequent variable leaching processes that transport the uranium to deeper soil profiles, and by surface water runoff that transports the uranium away from the site. The tentative conclusions drawn from the comparison of CVs in this section are constrained by the small number of samples relative to those needed to reasonably estimate such variance. 13

2. Uranium in Soil Separates. Soil samples collected at $10 \mathrm{~m}$ from the detonation point were obtained from areas in which the vegetative cover was very sparse, soil profiles were moderately eroded by wind and water, and particle sizes characteristic of coarse sand, very coarse sand, and coarse fragments constituted $30 \%$ of the soil mass. Soils at greater distances, such as 150 and $200 \mathrm{~m}$, contained finer material and showed little water erosior effects; 'h $h$ y were characterized by $40 \%$ silt-clay, $35 \%$ sand, and small amounts of tire larger size fractions, as shown in Fig. 2. The distribution of the uranium inventory particle size categories 
TABLE II

VARIATION IN E-F SITE SURFACE (0- to 2.5-Cm-DEEP)

SDIL SAMPLES AT VARIOUS DISTANCES FROM THE DETONATION POINT

\begin{tabular}{l} 
Distance \\
\hline$(\mathrm{m})$ \\
\hline 0 \\
10 \\
20 \\
30 \\
40 \\
50 \\
75 \\
100 \\
150 \\
200
\end{tabular}

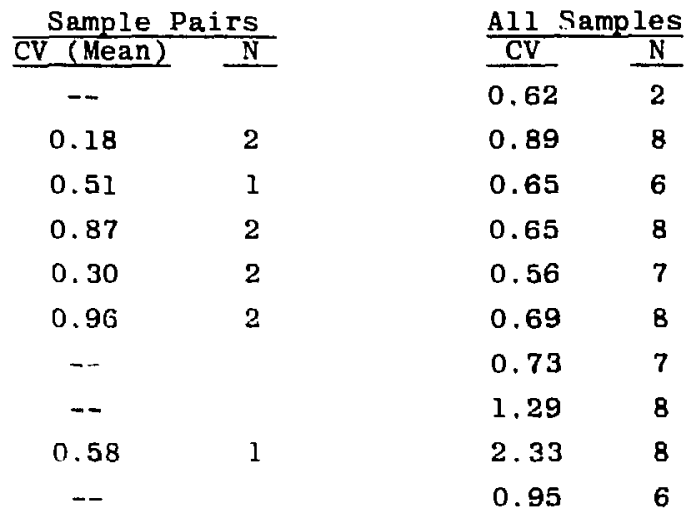

in soil cores were calculated by multiplying the uranium concentration by the mass of each fraction. Those taken at $10 \mathrm{~m}$ from the detonation point tended to closely parallel the soil masses in those categories. but they showed a shift toward more small uranium ( $<53-\mu \mathrm{m})$ particles and fewer large particles than in the soil mass. Only $2 \%$ of either the uranium or the soil mass in the 53- to 105- $4 \mathrm{~m}$ size range at the $10-\mathrm{m}$ distance. This suggested that we may have encountered soil particles contaminated with uranium rather than uranium particles per se. However, uranium particles of $<500-4 \mathrm{~m}$ diameter constituted a greater fraction of the total uranium inventory with increasing distance from the detonation point than did. soil particles, indicating appreciable deposition of relatively smal] uranium particles over the past several years of tests at F-F Site.

The per cent of uranium in the three smallest size fractions was consistently greater than the masses of those fractions in both depth increments, illustrating the predominance of particles <500-um diameter therein.

Uranium concentrations in the sis soil size fractions from the $0-$ to $5-\mathrm{cm}$ and 5to 10-cm depths are graphically presented in Figs. 3 and 4 . The appreciable variation in uranium values as a function of both distance from the firing point and depth in the soil profile constrains a strict interpretation of the data. However a general decrease of uranium concentrati:n in soil with distance is apparent and a generalized interpretation may be made that small uranium particles predominated at the 10-m distance in both soil column increments; larger ( $1-$ to $2-\mathrm{mm}$ ) particles assumed major importance in the 20- to 50-m distances, with a fair representation of intermediate-sized ( $105-$ to 500- $\mu \mathrm{m}$ ) particles; and most of the uranium at the periphery of the circular study area was again associated with $<1000-\mu m$ particles. The distribution with distance may have been

TABLE III

COEFFICIENTS OF VARIATION OF UAANIUM CONCENTRATION IN VARIOUS DEPTH INCREMENTS

OF DUPLICATE SOIL CORES SAMPLED $0.5 \mathrm{~m}$ APART AT E-F SITE

\begin{tabular}{|c|c|c|}
\hline $\begin{array}{l}\text { Soil Depth } \\
(\mathrm{cm})\end{array}$ & $\begin{array}{c}\mathrm{CV} \\
\text { (mean) } \\
\end{array}$ & $\mathrm{N}$ \\
\hline $0-2.5$ & 0.57 & 10 \\
\hline $2.5-5$ & 0.44 & 9 \\
\hline $5-10$ & 0.52 & 9 \\
\hline $10-15$ & 0.71 & 8 \\
\hline $15-20$ & 0.94 & 5 \\
\hline $20-30$ & 0.78 & 3 \\
\hline
\end{tabular}



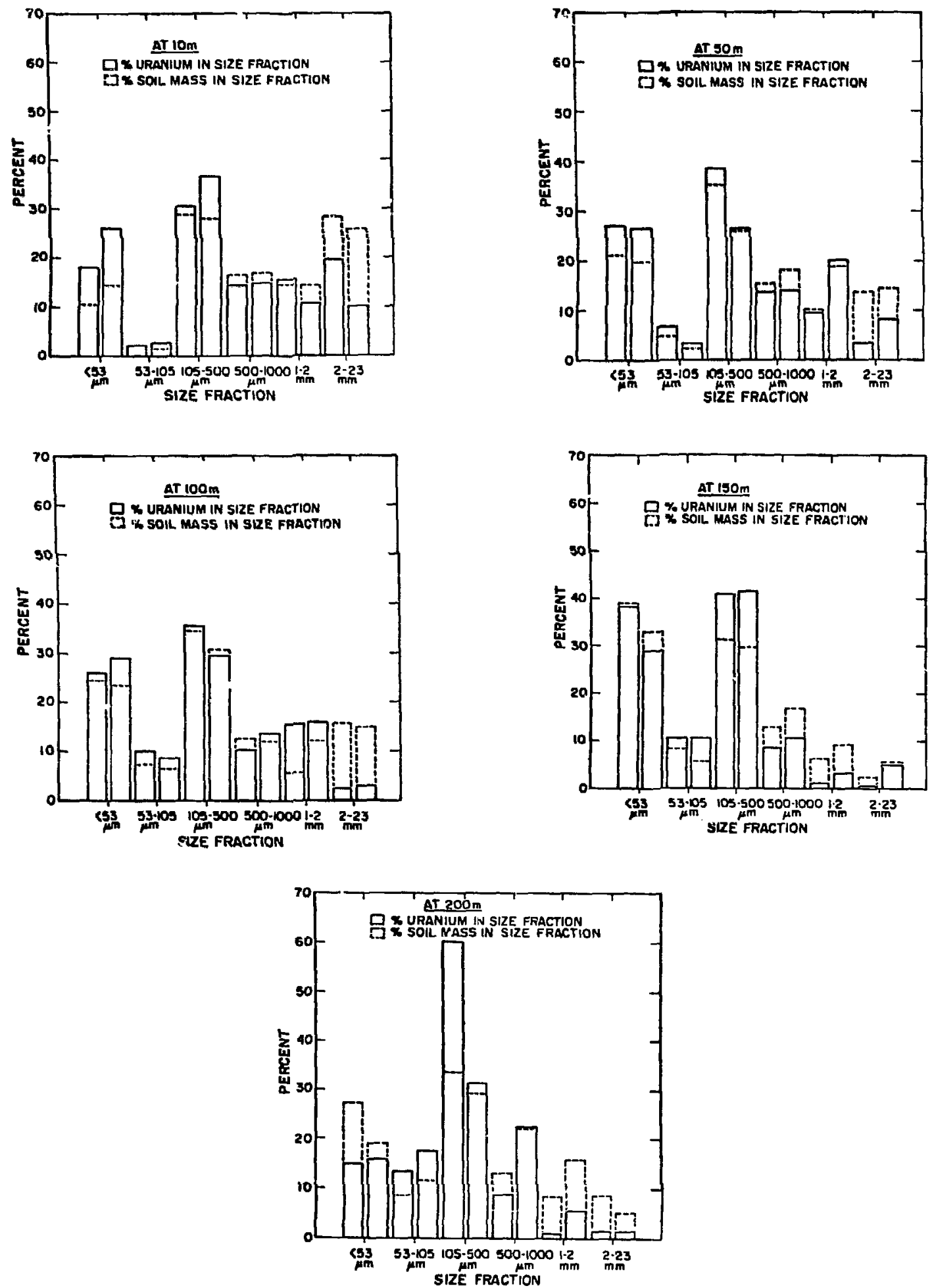

Fig. 2. The per cent of the total uranium and per cent soil mass associated with each size fraction as a function of soil depth at $10,50,100,150$, and $200 \mathrm{~m}$ from the detonation point. The left-side bar for each size fraction is for the 0- to 5-cm depth and the right-side bar is for the 5- to $10-\mathrm{cm}$ depth. 
affected to an unknown degree by the placement of the detonation point at the base of the northern mound (see Fig. 3, of Ref. 1), which would have caused an asymmetical dispersion of uranium and other debris from explosive tests.

\section{Uranium Inventory Estimates by}

Annuli and Isopleth Methods. The parameters used to estimate the uranium inventory in E-F Site surface ( $0-$ tu 5-cm-deep) soils by the two different techniques are presented in Tables IV and $V$. The method in which the median uranium concentration at each of 10 sampling distances from the detonation point was used (Table IV) to calculate an inventory within that annulus yielded an estimated $4480 \mathrm{~kg}$ within a surface area of $125590 \mathrm{~m}^{2}$, including about $6000 \mathrm{~m}^{2}$ in annuli south of the $150-m$ sampling point. The second inventory estimate of about 2970 kg within a surface area of $119140 \mathrm{~m}^{2}$ was obtained by using areas within uranium concentration isopleths (Fig. 5) and their

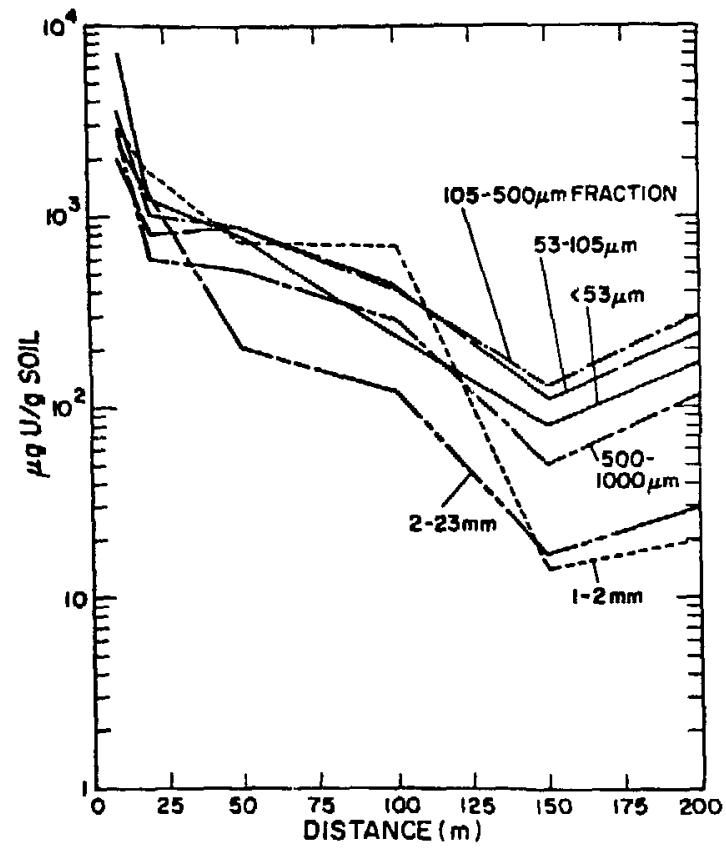

Fig. 3. Uranium concentrations in soil size fractions as a function of distance in the $0-$ to $5-\mathrm{cm}$ horizon at $E-F$ Site. respective median uranium concentrations (Table V). As noted, the $6000-\mathrm{m}^{2}$ discrepancy in total surface areas used in the calculations resulted from the lack of data from the 200-m sampling location south of the detonatiun point because that location falls within Potrillo Canyun and prevented extrapolation of the isopleths to that region. I $F$ we assume that the 100- to 300$\mu \mathrm{g} / \mathrm{E}$ uranium isopleth is applied to that area, the estimate is changed by only $2 \%$.

The total uranium (in kilograms) and the per cent of the estimated uranium inventory witlin each annulus (Table IV) reflects the magnification produced by surface area and soil mass parameters used in ubtaining the estimate by the first method. Note that the 125- to $175-m$ segment contained $37.5 \%$ of the surface area and $54 \%$ of the uranium inventory, or a ratio of 1.4 between the per cent of the total uranium and the per cent of total surface area in

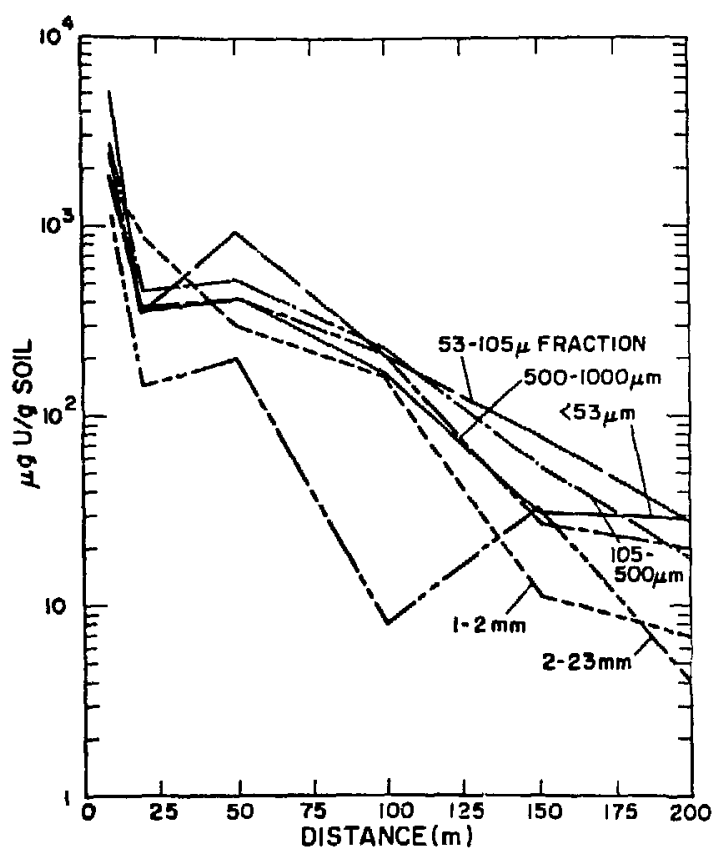

Fig. 4. Uranium concentrations in soil size fractions as a function of distance in the 5- to $10-\mathrm{cm}$ horizon at $E-F$ Site. 
TABLE IV

ESTIMATED UTALILU INVENTORY IN SURFACE SOIJS (0- to 5-cm) AT E-F SITE DETERMINED BY SUMAING URANIUM CONCENTRATIONS IN ANNULI

\begin{tabular}{|c|c|c|c|c|c|c|c|}
\hline $\begin{array}{l}\text { Distancs } \\
\frac{(m)}{}\end{array}$ & $\begin{array}{l}\text { Aumber } \\
\text { of } \\
\text { Samples }\end{array}$ & $\begin{array}{l}\text { Surface } \\
\text { Area of } \\
\text { Annulus } \\
\left(m^{2}\right) \\
\end{array}$ & $\begin{array}{c}\text { Per Cent or } \\
\text { Tolal } \\
\text { Surtace } \\
\text { Area in } \\
\text { Aniulus } \\
\end{array}$ & $\begin{array}{c}\text { Median } \\
\text { Uranium } \\
\text { Concentration } \\
(\mu g / g) \\
\end{array}$ & $\begin{array}{c}\text { Total } \\
\text { uranium } \\
\text { in } \\
\text { Annulus } \\
-(\mathrm{kg}) \\
\end{array}$ & $\begin{array}{c}\text { Per Cent } \\
\text { Uranium } \\
\text { in } \\
\text { Annulus } \\
\end{array}$ & $\begin{array}{l}\text { \% Lranium/ } \\
\text { \% Surface Alea }\end{array}$ \\
\hline $0-5$ & 2 & 78 & 0.06 & 4750 & 26.1 & 0.6 & 10 \\
\hline $5-15$ & 8 & 628 & 0.5 & 4915 & 215.6 & 4.8 & 9.6 \\
\hline $15-25$ & 6 & 1257 & 1.0 & 835 & 73.6 & 1.6 & 1.6 \\
\hline $25-35$ & 8 & 1885 & 1.5 & 1330 & 175.4 & 3.9 & 2.6 \\
\hline $35-45$ & 7 & 2513 & 2.0 & 710 & 194.7 & 2.8 & 1.4 \\
\hline $.15-55$ & 8 & 3142 & 2.5 & 475 & $10-4.5$ & 2.3 & 0.9 \\
\hline 55-87.5 & 7 & 14550 & 11.6 & 350 & 358.5 & a. 0 & 0.7 \\
\hline $87.5-125$ & $\mathbf{B}$ & 35075 & 19.9 & 370 & 651.9 & 14.5 & 0.7 \\
\hline $125-175$ & 8 & 47124 & 37.5 & 730 & 2414.7 & 53.8 & 1.4 \\
\hline $175-200$ & 7 & 29453 & 23.4 & 165 & 340.2 & 7.6 & 0.3 \\
\hline is $0-200$ & 69 & $\overline{125592}$ & 100 & $1240=196$ & 4485.2 & 100 & \\
\hline
\end{tabular}

the circular study area, as shown in the last column. Such ratios were generally parcostional to the changes in the uranium conc entrations more than to changes in the suif ice area. This illustrated that an overestimate of the inventory might well have been introduced by a single large uranium concentration value that sharply increased the mean uranium value for that particular segment. By deleting that datum, the mean uranium value for the 125- to 175$m$ segment was decreased by a factor of 5 , and similarly reduced the uranium inventory estimate to ahnut $2600 \mathrm{~kg}$. However, we believe that such anomolies represent a "real world" situation that results from the common occurrence of large uranium particles away from the detonation point.

In the isopleth method of estimating the uranium inventory, over $90 \%$ of the surface area was associated with two concentration gradients; $60 \%$ was within the 100to 300-ug $\mathrm{U} / \mathrm{g}$ soil isopleth and $31 \%$ was in the 300- to 1000-ug U/g soil isopleth. The respective portions of the uranium inventory within these areas was 56 and 25\%. The ratio of per cent uranium inventory to surface area determined by the isopleth method shown in the last column of Table $V$ was less consistent than in the annulus method but also showed a rapid decrease with distance from the detonation point.

From these exercises we have estimated that the uranium inventory in the $0-$ to $5-\mathrm{cm}$ soil horizon at E-F Site is between 3000 and $4500 \mathrm{~kg}$, not including particles $>6 \mathrm{~mm}$ in size, which were screened from the samples during processing for whole soil sample analyses. The uranium inventory in the >6-mm particle size fraction could not be

TABLE $V$

ESTIMATED UR. IUM INVENTORY IN SURFACE SOILS (0- to 5-cm) AT E-F SITE

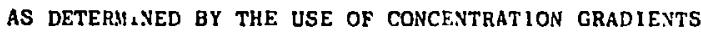

\begin{tabular}{|c|c|c|c|c|c|c|c|}
\hline $\begin{array}{l}\text { Isopleth } \\
(\mu \mathrm{g} / \mathrm{g})\end{array}$ & $\begin{array}{l}\text { Number of } \\
\text { Sampling } \\
\text { Locntions } \\
\text { Within } \\
\text { Isopleth }\end{array}$ & $\begin{array}{l}\text { Surtace } \\
\text { Arga } \\
\left(m^{2}\right) \\
\end{array}$ & $\begin{array}{l}\text { Per Cent } \\
\text { Surface } \\
\text { Area In } \\
\text { Isopleth } \\
\end{array}$ & $\begin{array}{c}\text { Mledian } \\
\text { Uranium } \\
\text { Concentration } \\
\text { (ug/g) } \\
\end{array}$ & $\begin{array}{c}\text { Total } \\
\text { Uraniuni } \\
\text { in Isopleth } \\
\text { (kg) } \\
\end{array}$ & $\begin{array}{l}\text { Per Cent } \\
\text { Uranium } \\
\text { in } \\
\text { Isopleth }\end{array}$ & $\begin{array}{l}\text { q. Uranium/ } \\
\text { g Surface Area }\end{array}$ \\
\hline$>3000$ & 3 & 611.6 & 0.5 & 6300 & 261.2 & 8.8 & 17.6 \\
\hline $1000-3000$ & 14 & 2629.9 & 2.2 & 1500 & 276.1 & 9.3 & 4.2 \\
\hline $300-1000$ & 32 & 36746.8 & 30.8 & 650 & 1672 & 56.3 & 1.8 \\
\hline $100-300$ & 11 & 70965.5 & 59.6 & 150 & 745.1 & 25.1 & 0.4 \\
\hline $30-100$ & 3 & 2729.3 & 2.3 & 65 & 12.4 & 0.4 & 0.2 \\
\hline Totals & $\overline{67}$ & $\overline{119141.7}$ & & & $\overline{2972,3}$ & & \\
\hline
\end{tabular}




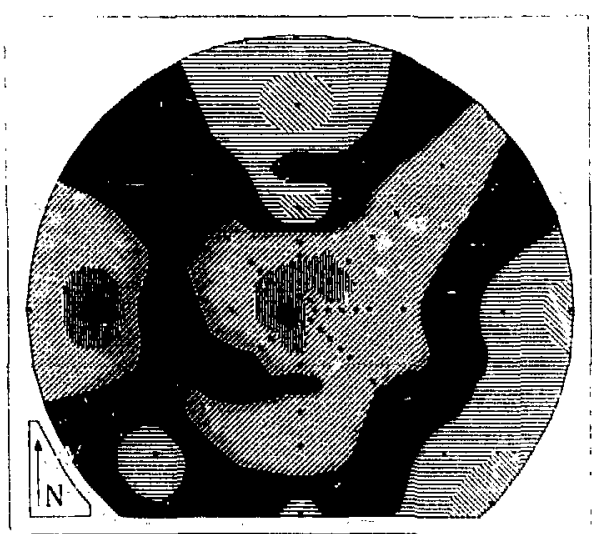

URANIUM CONCENTRATIONS AT E-F SITE

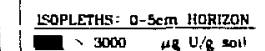

1000 - 3000

$300-1000$
$100-300$

:

(

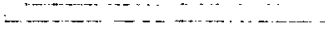

Fig. 5. Calculated isopleths of uranium concentrations in the 0 - to $5-\mathrm{cm}$ soil horizon at E-F Site.

reasonably estimated because of its highly ipregular distribution over the land surface.

D. Bagnold Collection of Redistributed Urarium Particles

Wirds can initiate three basic types of soil movement that cause redistribution of particulate materials: surface creep, saltation, and suspension. ${ }^{14}$ surface creep involves particles in the 500- to $1000-\mu m-$ diam range that are pushed along the ground surface by strong winds or by absnrption of momentum from smaller particles in saltation. Saltation consists of wind-driven 100- to 500-um-diam particles that bounce within a few centimeters of the ground surface Suspension, or reflotation, is the liftint and becoming completely airborne of f'ne particles <100 $\mu \mathrm{m}$, with those <10 $\mu \mathrm{m}$ possibly being suspended almost indefinitely. Several different mechanisms are involved in these three phenomena and their interpretation is often highly technical, depending upon the nature of the particulate material and the environmental setting being considered. Two very important considerations are surface soil texture and moisture content, the latter of which we have not examined because of the nighly variable soil moisture at E-F site.

Initial results from the Bagnold collectors (Table VI) maintained for 3 months at the E-F Site detonation point and $40 \mathrm{~m}$ downwind suggested that uranium particles $>100 \mu \mathrm{m}$ in diameter or those expected to move by surface creep and saltation, were most active at the ground surfice of the detonation point. Fine particulates with relatively high uranium concentrations predominated in the heights above $0.5 \mathrm{~cm}$, demonstrating the importance of suspension in redistribution of uranium. Samples fror. the collector located $40 \mathrm{~m}$ from the detonation point were more uniform in uranium concentration and per cent of uranium in the two size fractions, except for those from the highest collection slot. The larger particle sizes predominated in samples of airborne soil $<30$ to $45 \mathrm{~cm}$ above the ground surface and the smaller size fraction became increasingly important abuve that height. Essentially all of the uranium sampled at 60 to $75 \mathrm{~cm}$ above the surface was in particles of <100-um diameter.

A total of 38.6-mg uranium was sampled by the Bagnold apparatus at the detonation point during the 3 months of exposure compared to 7.9-mg uranium obtained from the instrument located $40 \mathrm{~m}$ downwind. The per cent of uranium associated with the two size fractions at each height indicated that a greater sample mass was collected in the $>100-\mu \mathrm{m}$ fraction and that $62 \%$ of the uranium was collected within $30 \mathrm{~cm}$ of the ground surface at the detonation point. At the more distant Bagnold sampler, about $50 \%$ of the uranium was collected at ground level and $94 \%$ was collected within $30 \mathrm{~cm}$ of the surface. The soil particle size analyses reported earlier ${ }^{1,2}$ also showed that the 100-um particles compose the largest portion of the soil mass near the two sampling locations. Although the meteorological data 
TABLE VI

SOIL URANIUM CONCENTRATIONS AND PER CENT LRANIUM IN TWO SIZE FRACTIONS COLLECTED FROM BAGNOLD DUST COLLECTORS MAINTATNED AT E-F SITE

FROM APRIL TO JULY 1977

\begin{tabular}{|c|c|c|c|c|c|}
\hline \multirow[b]{3}{*}{$\begin{array}{l}\text { Height } \\
(\mathrm{cm})\end{array}$} & \multirow[b]{3}{*}{$\begin{array}{c}\text { Size } \\
\text { Fraction } \\
(\mu \mathrm{m})\end{array}$} & \multicolumn{4}{|c|}{ n Location } \\
\hline & & \multicolumn{2}{|c|}{ Detonation Point } & \multicolumn{2}{|c|}{$40 \mathrm{~m} \mathrm{NE}$ of Detonation Point } \\
\hline & & $\begin{array}{c}\text { Uranium } \\
\text { Concentration } \\
(\mu g / g)\end{array}$ & $\begin{array}{c}\text { Per Cent } \\
\text { Uranium in } \\
\text { Size Fraction }\end{array}$ & $\begin{array}{l}\text { Uranium } \\
\text { Concentration } \\
(\mu \mathrm{g} / \mathrm{g})\end{array}$ & $\begin{array}{c}\text { Per Cent } \\
\text { Uranium in } \\
\text { Size Fraction }\end{array}$ \\
\hline \multirow[t]{2}{*}{$0-0.5$} & $<100$ & 481 & 21 & 1500 & 48 \\
\hline & $>100$ & 755 & 79 & 1060 & 52 \\
\hline \multirow[t]{2}{*}{$0.5-15$} & $<100$ & 12700 & 57 & 750 & 48 \\
\hline & $>100$ & 1420 & 43 & 810 & 52 \\
\hline \multirow[t]{2}{*}{$15-30$} & $<100$ & 11900 & 55 & 2710 & 42 \\
\hline & $>100$ & 1780 & 45 & 3100 & 58 \\
\hline \multirow[t]{2}{*}{$30-45$} & $<100$ & 10800 & 59 & 1500 & 50 \\
\hline & $>100$ & 1510 & 41 & 1010 & 50 \\
\hline \multirow[t]{2}{*}{$\angle 5-60$} & $<100$ & 10700 & 56 & 2300 & 54 \\
\hline & $>100$ & 1380 & 44 & 1000 & 46 \\
\hline \multirow[t]{2}{*}{$60-75$} & $<100$ & 14000 & 50 & 4400 & 100 \\
\hline & $>100$ & 1420 & 50 & 19 & $<1$ \\
\hline
\end{tabular}

have not been reduced to the summary form necessary to assess the implications of wind speed and direction to the redistribution of uranium, the above data indicate that surface creep and saltation are important natural agents affecting surface transport of uranium at E-F site. Surface water runoff was previously implicated as the major means of uranium movement in the transfer of about $58 \mathrm{~kg}$ of uranium from E-F Site to a 9000-m sector of adjacent Potrillo Canyon over a 23-yr period. 2

E. Uranium Concentrations in Smal1-Mammal Tissues

Our 1976 report, 1 which contained a very limited number of analyses from pocket gopher (Thomomys bottae) tissues collected during November 1974, indicated a difference in uranium concentrations between that subterranean species and the surface-active deer mice (Peromyscus maniculatus). To extend this observation, a more intensive simultaneous collection of the two species was made during April and May 19\%7 and uranium analyses were obtained for six sample types. Results (Table VII) indicated that there was a difference between uranium concentrations in the several tissue types and that deer mice generally contained higher mean uranium concentrations in their tissues than did pocket gophers. These data are consistent wi'; the 1976 results and confirmed our previous observations in most areas; however, several aspects of the data require amplification. An important difference between 1976 and 1977 (Table VII) results is the much higher uranium concentration in the 1977 sanples except in the lungs of deer mice. In most cases the current levels are 2 to 100 times those measured in the animals collected during November 1974 or June 1975, even though no additional releases of uranium occurred at E-F Site during the interim. Therefore, we can only speculate about the reasons for the higher levels. 
TABLE VII

URANIUM CONCENTRATIONS IN TISSUE SAMPLES FROM TWO SYMPATRIC SPECIES OF SMALL MAMMALS AT LASL E-F SITE (APRIL - MAY 1977)

\begin{tabular}{|c|c|c|c|c|c|c|c|}
\hline \multirow[b]{2}{*}{ Species } & \multirow[b]{2}{*}{ Sample } & \multicolumn{4}{|c|}{ Uranium Concentration $(u E / g)$} & \multirow[b]{2}{*}{$\mathrm{CV}$} & \multirow[b]{2}{*}{$\mathrm{N}$} \\
\hline & & Mean & Median & Minimum & Maximum & & \\
\hline Peromyscus & GI & 900 & 380 & 140 & 3600 & 1.49 & 6 \\
\hline Thomomys & & 220 & 75 & $<0.5^{\mathrm{a}}$ & 720 & 1.15 & 8 \\
\hline Peromyscus & Pelt & 500 & 300 & 140 & 1530 & 1.07 & 6 \\
\hline Thomomys & & 200 & 120 & 9.1 & 460 & 0.91 & 8 \\
\hline Peromyscus & Lung & 4.4 & $<0.5$ & $<0.5$ & 24 & 2.18 & 6 \\
\hline Thomomys & & 5.7 & $<0.5$ & $<0.5$ & 42 & 2.44 & 8 \\
\hline Peromyscus & Carcass & 6.8 & 2.9 & $<0.5$ & 30 & 1.69 & 6 \\
\hline Thomomys & & 4.3 & 1.0 & $<0.5$ & 16 & 1.23 & 8 \\
\hline Peromyscus & Ki dney & 30 & $<0.5$ & $<0.5$ & 140 & 1.85 & 6 \\
\hline Thomomys & & 21 & $<0.5$ & $<0.5$ & 160 & 2.45 & 8 \\
\hline Peromys us & Liver & 23 & 18 & $<0.5$ & 60 & 1.02 & 6 \\
\hline Thomomys & & 10 & $<0.5$ & $<0.5$ & 58 & 1.90 & 3 \\
\hline
\end{tabular}

Minimum detectable limit.

Several environmental and physiological parameters are substantially affected by the seasonal differences that are represented by the November 1974 and April-May 1977 collection periods. Soil moisture varies strongly with season and is probably one of the major tactors that influences the bicavailability of uranium in the upper few millimeters of soil. This possibility is suggested by the appreciable differences between Peromyscus pelt samples taken in November 1974 ( $24 \mathrm{\mu g} / \mathrm{g})$, June $1975(49 \mathrm{\mu g} /$ g), and April-May 1977 (500 $\mu \mathrm{g} / \mathrm{g})$. Food habits of the small mammals vary appreciably; the pocket gopher is a vegetarian heavily dependent upon plant roots and other vegetative plant parts, whereas the deer-mose diet shifts from a preponderance ( $94 \%$ ) of seeds, fruits, and roots during winter to mostly animal focds ( $76 \%$ large insects and other invertebrates) during spring and then to mostly plant foods (68\%) during summer. ${ }^{15}$ Although the food habits would presumably influence the concentrations of uranium in internal organs, appreclable amounts of soil and uranium are ingested by small mammals during their normal grooming. The relatively low fraction $\left(<10^{-4}\right.$ ) of uranium transferred from the GI track to blood presumably accounts for the modest concentrations found in carcass and lung samples and mitigates the consequences of ingestion of uranium from whatever source. The amounts of uranium in deer mouse and pocket gopher lung samples collected during 1977 were similar to one another and to carcass values, arguing against appreciable inhalation of uranium particles; positive values occurred in only one specimen of each species.

The uranium concentrations for tissue samples presented in Table VII illustrate that the range of values was extremely large, often positively skewed, and highly variable. Such characteristics are indicated by CVs almost consistently $>1.0$, which complicates the strict interpretation of the data and suggests that a much larger number of samples would be necessary to provide conclusive results. The variation apparently results from the particulate nature of uranium, its density and mobility 
in the environment, and the variable habits of the animals.

A possible explanation for some of the differences between the 1977 data and that obtained in $1974 \cdots 1975$ is the change of analytical methods that was discussed in Sec. II.A. The earlier samples were processed by FA, which is less sensitive than IENAA and requires that the sample be put in solution. This offers the possibility for some variable portion of the uranium to become adsorbed in the residue matrix and to be missed when an aliquot of the dissolved sample is analyzed.

The results for both mammalian species showed that the highest uranium concentrations were in GI tract contents and that slightly lower values were in pelts. Kidneys and livers contained about 5 to $10 \%$ or pelt values, and lungs and carcass samples contained amounts that were slightly above background. The data substantiate our previous report that the greater bioavailability of uranium in the top few millimeters of soil at E-F Site results in greater contamination of the deer mouse population than of the pocket gopher population.

F. Macrofauna Studies

1. Numbers of Individuals and Species Taken by Various Collection Methods. There was no consistent difference between either the numbers of individual invertebrates or the numbers of species captured in pitfall traps (Table VIII). The taxonomic orders Acarina, Hymenoptera, and Hemiptera were most strongly represented. Acarina were most abundant during Apr $\$ 1$, decreased during warmer months, and then increased during November. Hymenoptera and Hemiptera showed a reverse pattern of abundance, with low population densities during spring and autumn months and greatest abundance during summer months.

Sweep net results are summarized in Table IX. A greater number of individual invertebrates were usually captured in the test areas rather than in their controls during the sampling periods, even though the mean number of species per sample and the total number of species per sampling period were similar for both test and control areas. A total of 63 species were identified at the E-F test area and 61 species at its control area; at the LS test area, 43 species were collected compared to 53 species at its control area.

Relative densities ( $R D=$ per cent of total animals) of most single species or larger taxa Indicated that there were preferences toward individual sampling sites rather than selection against test areas. For example, Thysanoptera had an overall RD of $48 \%$ at the E-F test area and $4 \%$ at its control area. This order showed an opposite relationship at LS Site, where RDs of 0.3 and $14 \%$ occurred at the test and control areas, respectively. Coreid, mirld, and cicadellid bugs were the only species whose abundance suggested a preference for control rather than test areas and iphids were the single taxon with greater abundance at both E-F and LS test areas.

Herbivorous species constituted $>65 \%$ of the total individuals collected by sweep net and carnivores made up $\sim 10 \%$ of the total; the remainder consisted of omnivores, scavengers, or species whose food habits are unknown or ill-defined.

Therefore, the overall comparisons of numbers of individuals and numbers of species obtained by pitfall traps and sweep nets revealed no conclusive evidence of a gross differential response to the areas of relatively high uranium concentrations in soils and to nearby control areas.

2. Distributions of the Major Invertebrate Orders. Analysis of the results obtained by the three sampling techniques used during the various years of study (Tullgren funnel extraction of invertebrates from soil cores, pitfall trapping, and insect net sweeps) indicated that the greatest numbers of animals were obtained from soil cores and pitfall trapping, that only 10 to $20 \%$ as many animals were obtained by sweep net, and that results from 
TABLE VII I

MEAN NUMBERS OF INDIVIDUALS AND SPECIES OF INVERTEBRATES COLLECTED BY PITFALL TRAPS AT LASL SITES DURING 1976

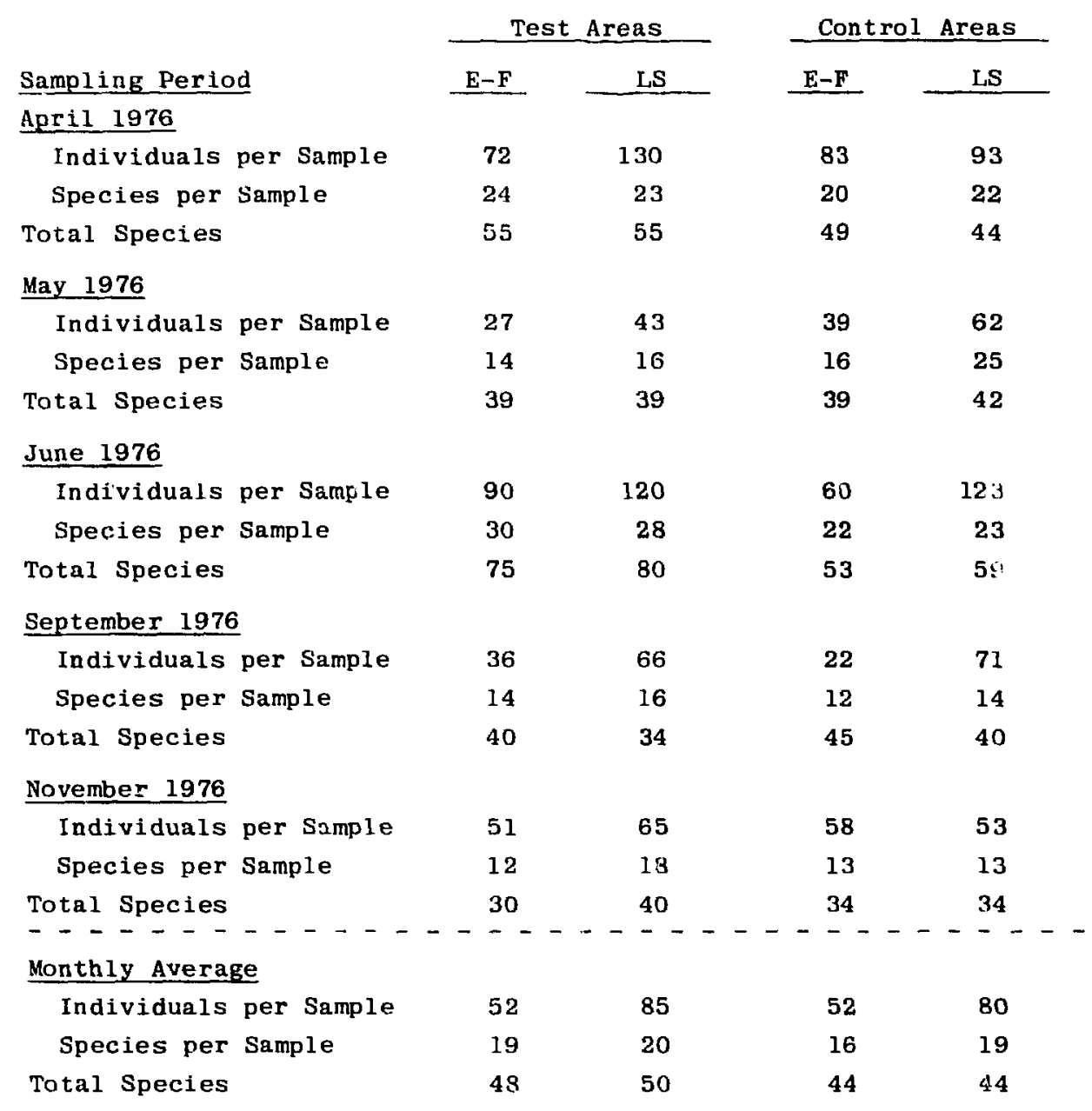

the test areas and their controls were inconsistent among the three teciniques. $A_{i} t$ E-F Site, the numbers of individuals anci numbers of species collected from control area soil cores were greater than frota test area cores. Sweep net results were tactly the opposite, with more than twice as many individuals per sample from the test area compared to the control area but with a similar number of species obtained from both areas. LS sample compositions were the reverse of those from E-F Site, with the LS test area yielding more individuals compared to the LS control area but with a greater number of species in the soil cores. Pitfall collections were similar in both test and control areas.

Specific distributions of the various orders were as follows:

a. Acarina (Ticks and Mites). This order was most abundant in soil cores and pitfalls and nearly absent in net sweeps. It consisted of 30 to 50 species and constituted from 50 to $90 \%$ of the total invertebrates obtained from soil and pitfall samples during all sampling periods. Population densities determined from pitfall 
TABLE IX

MEAN NUMBEAS OF INDIVIDUALS AND SPECIES OF INVERTEBAATES COLLECTED BY SWEEP NET AT LAST SITES DURING 1975 AND 1976

\begin{tabular}{|c|c|c|c|c|}
\hline \multirow[b]{2}{*}{ Sampling Period } & \multicolumn{2}{|c|}{ Test Areas } & \multicolumn{2}{|c|}{ Control Areas } \\
\hline & E-F & $\mathbf{L S}$ & $\mathbf{E}-\mathbf{F}$ & LS \\
\hline \multicolumn{5}{|l|}{ November 1975} \\
\hline Individuals per Sample & 1.7 & 94 & 10 & 11 \\
\hline Species per Sample & 1.7 & 3.3 & 1.7 & 4 \\
\hline Total Species & 4 & 6 & 4 & 11 \\
\hline \multicolumn{5}{|l|}{ February 1976} \\
\hline Individuals per Sample & 12 & 1 & 1 & 1 \\
\hline Species per Sample & 4.7 & 0.7 & 1.3 & 0.3 \\
\hline Total Species & 10 & 2 & 4 & 1 \\
\hline \multicolumn{5}{|l|}{ March 1976 } \\
\hline Individuals per Sample & 2 & 4.7 & -- & 3.7 \\
\hline Species per Sample & 1.3 & 2.3 & -- & 1.7 \\
\hline Total Species & 3 & 6 & -- & 3 \\
\hline \multicolumn{5}{|l|}{ May 1976} \\
\hline Individuals per Sample & 24 & 7 & 28 & 34 \\
\hline Species per Sample & 8.3 & 4.7 & 5.3 & 10 \\
\hline Total Species & 21 & 9 & 13 & 22 \\
\hline \multicolumn{5}{|l|}{ September 1976} \\
\hline Individuals per Sample & 146 & 80 & 33 & 73 \\
\hline Species per Sample & 18 & 18 & 18 & 16 \\
\hline Total Species & 32 & 27 & 42 & 35 \\
\hline \multicolumn{5}{|l|}{ November 1976} \\
\hline Individuals per Sample & 18 & 6 & $\mathbf{5}$ & 12 \\
\hline Species per Sample & 12 & 18 & 13 & 13 \\
\hline Totil Species & 30 & 40 & 34 & 34 \\
\hline Monthly Average & --- & $--\rightarrow$ & -- & --- \\
\hline Individuals per Sample & 34 & 32 & 15 & 23 \\
\hline Species per Sample & 7.7 & 7.8 & 7.9 & 7.5 \\
\hline Total Species & 17 & 15 & 19 & 18 \\
\hline
\end{tabular}

collections were similar for all sites and did not confirm earlier soil core results that showed significantly greater densities of Acarina at the E-F control area than at the test area and a reverse situation at the LS Site. Populations were highest during autumn, winter, and early spring, then decreased during warm months. About twothirds of the identified species were carnivores.

b. Araneida (Spiders). The spiders were usually most abundant in pitfall collections; and were taken less of ten in understory vegetation sweep samples. A few transients were collected from soil cores. population densities were similar in both 
test and control areas, as determined by all three collection techniques. Although the spiders consitituted a greater portion of the catch from net sweeps at the E-F areas, they represented on $1 y 8 \%$ of the total animals at the control area. Their actual abundance was greater in the pitfall collections than in collections by the other capture methods. Forty-five species of spiders were identified, most of them classified as predators.

\section{c. Collembola (Springtails). This} order was most aburdant in pitfall collections, was less common in soil cores, and was seldom taken in sweep net samples from vegetation. They were most abundant at the LS test area, where soil cores contained twice as many individuals as were in the pitfall samples. The E-F test and control area results showed an opposite trend, with significantly greater densities in control site soil cores and similar abundances in both test and control area pitfall collections. Collembola were usually most abundant during late spring and summer months. Most species of this order are scavengers.

d. Hymencptera (Ants and Wasps). Collections of this order consisted mostly of ants, which were most commonly taken in pitfall traps, reflecting their status as a wandering part of the insect community. Their relative densities were greater at LS than at E-F Site, and they were especially abundant in summer, when they made up 71 to $99 \%$ of the total individuals collected. Wasps instituted the major portion of sweep net samples; they are generally omnivores, but many species are herbivores whose larvae are carnivorous.

\section{e. Hemiptera (Homoptera and Heterop-}

tera)(Bugs). This is the major taxon associaled with vegetation; its members represented 50 to $80_{0}^{\circ}$ of the total specimens collected by sweep net. They were also common in pitfall samples, with a relative density of about $10 \%$ at all four areas. They occurred at very reduced densities in soil cores. The Hemiptera were more abundant at test areas than at control areas, a finding which contrasts with results from the soil core extractions reported last year. This order is mainly herbivorous.

f. Thysanoptera (Thrips). These animals were collected at about the same densities by all three methods, but were slightly more abundant in sweep net collections at the IS test area. Despite their low population densities they constituted 30 and $27 \%$ of samples at the LS test and control areas and 4 and $12 \%$ at the E-F test and control areas, respectively. This contradictory relationship of samples from test and control areas appeared in the 1976 results. This order is also mainly herbivorous.

F. Diptera (Flies). Population densities of flies were generally low, probably because the sampling techniques used in our studies were not efficient at capturing representative samples of flies. No consistent similarities or differences were noted in samples from experimental and control areas.

h. Coleoptera (Beetles). This largest order of insects was poorly represented in our samples, as illustrated by their relative density of $<2 \%$. As with the Diptera, other sampling techniques are required to obtain more representative samples. Greater densities were recorded in pitfall collections, but there were no consistent similarities or differences between control and test areas.

\section{Population Responses to Uranium.} These results substantiate our 1976 observations of invertebrate population densities in soil cores taken from LASL test and control areas. The 1976 and 1977 data taken by the three methods of collection indicate that environmental gradients other than the uranium concentration in surface soils affect invertebrate populations to such an extent that we cannot interpret their fluctuations as a response to uranium chemical toxicity. 
IV. SUMMARY AND CONCLUSIONS

A third year of study of the ecological consequences of exposure of terrestrial ecosystems at LASL to elevated soil concentrations of natural and depleted uranium was completed. Specific accomplishments included ( 1 ) development of a more accurate and expeditious method of uranium analysis, IENAA; (2) determination of natural and depleied-uranium concentrations in three sets of EAFB soils collected during range cleanup; (3) evaluation of inventory estimates, spatial distribution, and particle size correlations of uranium in soils at LASL E-F Site by annuli and isopleth methods; (4) demonstration of different uranium concentrations in organs and tissues of deer mice and pocket gophers from an area of high uranium concentrations in soils; (5) eraluation of surface transport of particulate uranium by the processes of surface creep, saltation and reflotation (suspension); and (6) summarization of two years' results of invertebrate population measurements made by soil core extractiuns, pitfall trapping, and insect net sweeping at two LASL test areas and their controls to evaluate the consequences of exposure to uranium.

Comparisons of uranium concentrations in a set of 33 soil samples and 2 standards determined by IENAA, DNA, and FA showed good agreement. A mean ratio of results from IENAA and FA methods was $0.94 \pm 0.19$ (std dev), indicating a slightly lower but trivial bias of the ratio. Considering these results, the significant reduction in cost and time for sample processing, and the increased reliability, IENAA was selected as the method to be used in most future uranium analyses in our laboratory.

The EAFB soil samples consisted of a set taken from barrels of contaminated soil removed from test ranges by a contractor and two sets of near-background samples. Uranium concentrations in the cleanup materials ranged from 30 to $4900 \mu \mathrm{g} / \mathrm{g}(=\mathrm{ppm})$ anci duplicate aliquots had CVs of 0 to 0.68 .
Spatial variability in sampling for uranium distribution by a polar coordinate system was evaluated by analysis of uranium concentrations in randomly selected duplicate soil cores taken at locations $0.5 \mathrm{~m}$ from and parallel to those reported last year. Variations for surface $(0-$ to $2.5-\mathrm{cm}-$ deep) soils averaged lowest $(0.18)$ in samples collected at $10 \mathrm{~m}$ from the detonation point and greatest $(0.96)$ at $50 \mathrm{~m}$. The individual variations ranged from 0.07 to 1.06 and showed no consistent pattern related to distance from the origin of the uranium, illustrating a strong influence of past chemical explosive tests conducted between 1943 and 1972 . Uranium concentrations in deeper ( $30-\mathrm{cm})$ soil cores showed that soil sampling results are strongly influenced by the variable deposition of past uranium debris, fragments from $2 \mathrm{~mm}$ to several centimeters in diameter, by the subsequent variable leaching processes that transport uranium to deeper soil profiles, and by surface water runoff of uranium to distant locations.

Uranium concentrations in six soil size fractions determined from forty $0-$ to $5-\mathrm{cm}-$ and 5- to $10-\mathrm{cm}-$ deep cores showed considerable variation but suggested that small ( $<53-u m)$ uranium particles predominated at $10 \mathrm{~m}$ from the detonation point; larger ( 1 - to $2-\mathrm{mm}$ ) particles assumed major importance at the 20 - to $50-m$ distances, with a fair representation of intermediatesized (105- to 500- $\mu \mathrm{m})$ particles; and most of the uranium at the periphery of the 12.6ha study area was again associated with small particles.

Two methods were used to calculate a total uranium inventory within a 12.6-ha circle centered on the E-F Site detonation point. The first consisted of calculating the surface area enclosed by an annulus at the midpoint between each sampling distance and applying a median uranium concentration derived from all sampling points within each area. The second method involved 
calculating the surface areas of soil uranium concentration isopleths and multiplying by the median uranium concentration for each isopleth. Inventory estimates of $4500 \mathrm{~kg}$ by the irst method and $3000 \mathrm{~kg}$ were obtained.

Initial results from Bagnold dust collectors maintained for 3 months at two locations near the E-F Site detonation poit indicated that uranium particles in the

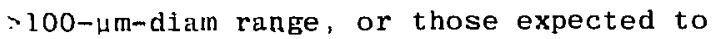
nove by surface creep and saltation, were most active at the ground surface. Fine particulates with relatively high uranium concentrations predominated in collector heights above $0.5 \mathrm{~cm}$, demonstrating the importance of suspension in the redistribution of uranium.

Uranium concentrations in tissues of deer mice (Peromyscus maniculatus) and pocket gophers (Thomomys bottae) collected at E-F Site indicated that there was a difference between amounts in several tissue types and that deer mice generally contained aigher mean uranium concentrations in their tissues than did pocket gophers. The 1977 resulis were 2 to 100 times those measured in similar samples collected during November 1974 and June 1975; however, the range of values was highly variable and reinforced our previous observations that an appreciably larger number of samples would be necessary to provide conclusive results. Highest uranium concentrations were in GI tract contents and slightly lower values were in the pelts. Kidneys and livers contained about 5 to $10^{\circ}$ of pelt values, and lungs and carcass sanples contained amounts that were slightly above background. These data support our previous conc'usion that the greater bioavailability o' uranium in the top few millimeters of soil at E-F site resulted in greater contamination of the deer mouse population than of the sympatric pocket gopher population.

Invertebrate populations in areas of high (2400- to $16000-\mu \mathrm{g} / \mathrm{g})$ and medium (20to $80-\mu g / g)$ uranium concentrations in soils were sampled by pitfall trapping and insect net sweeps to evaluate possible effects of exposure to such levels upon those antimals. The overall comparisons of numbers of individuals and numbers of species in the study areas revealed no conclusive evidence of a gross differential response to the areas of relatively high uranium concentrarions in soils and to control areas.

\section{ACKNOWLEDGMENTS}

Environmental Studies Group personnel who deserve recognition include $K$. V. Bostick for supervising sample processing; $P$.

E. Baldwin, M. A. Rosenthal, J. L. Martinez, and G. Trujillo for technical assistance; and E. S. Glidney and $P$. Jose for conducting uranium analyses. D. C. Lowrie separated, identified, and summarized soil nacrofauna; W. J. Smith helped generate computerized graphics; and G. C. Whitf jrovided statistical consultation. We thank all these people for their assistance

\section{REFERENCES}

1. W. C. Hanson and F. R. Miera, Jr. "Long-Term Ecological Effects of Exposure to Uranium," Los Alamos Scientific Laboratory report LA-6269 (July 1976 ).

2. W. C. Hanson and F. R. Miera, Jr., "Continued Studies of Long-Term Écological Effects of Exposure to Uranium," Ios Alamos Scientific Laboratory report LA-6742 (AFATL-TR-77-35) (June 1977).

3. US Energy Research and Development Administration, "ERDA Announces Plans for Nationwide Hydrogeochemical and Stream Sediment Program," News Release No. 29 (August 8, 1977), Grand Junction, $\mathrm{CO}, 3 \mathrm{pp}$.

4. A. Grimbert and R. Loriod, "Geochemical Prospecting for Uranium," AEC-TR-7579, translation from French, US AEC Office of Information Services, Technical Information Center, Springfield, VA, 38 pr.

5. A. Bjorkland, M. Tenhola, and R. Rosenberg, "Regional Geochemical Uranium prospecting in Finland (with discussion): Exploration for Uranium Ore Deposits, IAEA-SM-208/26, Vienna, 1976. pp. 283-296. 
6. I. R. Jonasson and W. D. Goodfellow, "Uranium Reconnaissance programs: Orientation Studies in Uranium Exploration in the Yukon," Geological Survey Canada Open File 388, Geological Survey Canada, Ottawa, 1976, $97 \mathrm{pp}$.

7. E. S. Gladney, W. K. Hensley, and M. M. Minor, "A Comparison of Three Techniques for the Measurement of Depleted Uranium in Soils," submitted to Anal. Chem. (1978).

8. J. W. Owens, "Fluorometric Determination of Uranium in Environmental Materials," Los Alamos Scientific Laboratory report LA-6338-MS (May 1976).

9. S. Amiel, "Analytical Applications of Delayed Neutron Emission in Fissionable Elements," Anal. Chem. 34, 16831692 (.1962).

10. E. Steinnes, "Epithermal Neutron Activation Analysis of Geological Material," in Activation Analysis in Geochemistry and Cosmochemistry, A. $O$. Brunfelt and E. Steinnes, Eds, (Universitets Furlaget, Oslo, 1971), pp. 115-128.
11. S. J. Balestrini, J. P. Balagna, and H. O. Menlove, "Two Spec: 2 lized Delayed-Neutron Detector Deigns for Assays of Fissionable Elements in Wate and Sediment Samples," Nucl. Instrum, Methods, $136,-521-524$ (1976).

12. G. R. Price, R. J, Ferretti, and $S$. Schwartz, "Fluorophotometric Determination of Uranium," Anrl. Chem. 25, 322-331 (1953).

13. G. C. White and T. E. Hakonson, "Statistical Considerations and Survey of Plutonium Concentration Variability in Some Terrestrial Ecosystem Componmnts, submitted to Health Phys. (1978).

14. J. E. Newman, M. D. Abe1, P. R. Harrison, and K. J. Yust, "rind as Related to Critical Flushi.: jieed Versus Reflotation Speed by High-Volume Sampler Particulate ioading," in AtmosphereSurface Exchange of Particulate and Gaseous Pollutants, R. J. Engelmann an G. A. Sehme1, Eds. (DOE Techinical Information Center, Oak Ridge, TN, 1976) pp. $466-494$.

15. A. C. Martin, H. S. Zim, and A. I. Ne] son, American Wildlife and Plants (MCGraw-Hill, Inc., New York, 1951) pp. 261-262.

APPENDIX

TABLE A-I

ANALYTICAL RESULTS FOR EAFB SOIL SANPTES

COLLECTED ON VARIOUS DATES IN 1976 AND 1977

\begin{tabular}{|c|c|c|}
\hline Date & EAFB No. & LASL No. \\
\hline June 76 & $\begin{array}{l}0-0 \\
1-1 \\
1-3 \\
1-5 \\
1-7 \\
1-9 \\
1-11 \\
1-13 \\
1-15 \\
1-17 \\
1-17 \text { (Replicate) }\end{array}$ & $\begin{array}{r}77.05071 \\
5072 \\
5073 \\
5074 \\
5075 \\
5076 \\
5077 \\
5078 \\
5079 \\
5080 \\
5154\end{array}$ \\
\hline & $\begin{array}{l}2-0 \\
2-2 \\
2-4 \\
2-6 \\
2-8 \\
2-10 \\
2-12 \\
2-14 \\
2-16 \\
3-1 \quad \text { (Replicate) } \\
3-1 \quad \text { ical }\end{array}$ & $\begin{array}{l}5081 \\
5082 \\
5083 \\
5084 \\
5085 \\
5086 \\
5087 \\
5088 \\
5089 \\
5090 \\
5155\end{array}$ \\
\hline
\end{tabular}

Uranium Concentration $(p p m=\mu g / g)$

Result \pm Uneertainty

$\begin{array}{rc}1 & 0.4 \\ 3 & 0.5 \\ 23 & 0.8 \\ 9 & 1 \\ 8 & 0.7 \\ 70 & 32 \\ 2 & 0.6 \\ 0.9 & 0.3 \\ 0.5 & 0.4 \\ 0.8 & 0.4 \\ 0.6 & 0.5 \\ 7 & \\ 38 & 0.6 \\ 1 & 1 \\ 2 & 0.3 \\ 1 & 0.4 \\ 2 & 0.3 \\ 4 & 0.5 \\ 30 & 0.5 \\ 0.8 & 1 \\ 3 & 0.3 \\ 2 & 0.7 \\ & 0.5\end{array}$


TABLE A-I (cont)

Date

6 Dec 76
FAFB No.

$$
\begin{aligned}
& 3-11 \\
& 3-13 \\
& 3-15 \\
& 4-0 \\
& 4-12 \\
& 4--4 \\
& 5-13 \\
& 5-15
\end{aligned}
$$

0-0

$1-1$

$1-1$ (Replicate)

$1-3$

$1-5$

$1=7$

1-9

$1-11$

1-13

$1-15$

$1-17$

2-0

2-2

2-2 (Replicate)

$2-4$

2-8

2-10

2-12

$2-14$

$2-16$

3-1

3-3

3-5

3-5 (Replicate)

3-7

$3-9$

3-11

3-13

3-15

3-17

4-0

4-2

4-4

4-6

4-6 (Replicate)

4-8

4-10

4-12

4-14

4-16

5-1

5-3

5-5

5-7

5-9

5-9 (Replicate)
LASL No.

77.05091

5092

5093

5094

5095

5096

5097

5098

5099

5100

5156

5101

5102

5103

5104

5105

5106

5107

5108

5109

5110

5157

5111

5112

5113

5114

5115

5116

5117

5118

5119

5120

5158

5121

5122

5123

5124

5125

5126

5127

5128

5129

5130

5159

5131

5132

5133

5134

5135

5136

5137

5138

5139

5140

5160
Uranium Concentration

$\frac{(\mathrm{ppm}=\mu \mathrm{g} / \mathrm{g})}{\text { Uncerult }} \underset{\text { Uncertainty }}{ \pm}$

$\begin{array}{rl}0.6 & 0.3 \\ 3 & 0.1 \\ 49 & 2 \\ 0.7 & 0.3 \\ 2 & 0.4 \\ 50 & 0.8 \\ 2 & 0.4 \\ 21 & 0.4\end{array}$

1160

5
7

$36 \quad 4$

34

46

3

16

21

0,6

4

48

0.3

0.3

0.4

0.4

36

1

0.3

0.3

0.4

0.5

0.2

0.3

0.8

1053

$16 \quad 0.4$

0.3

0.3

0.2

0.3

0.4

0.5

0.5

3

0.4

0.5

0.5

0.4

0.5

0.5

0.9

0.4

0.6

0.6

0.6

0.4

0.4

0.4

0.4

0.5

0.8

0.4

0.5

0.5

0.6

0.4

0.7

0.3 
TABLE A-I (cont)

Date

EAFB No.

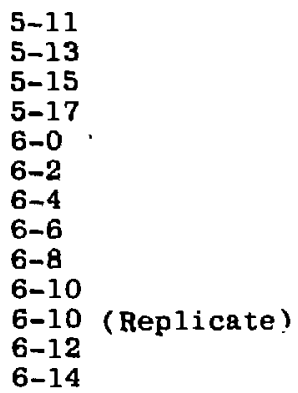

4 April 77
LASL NO.

77.05141

5142

5143

5144

5145

5146

5147

5148

5149

5150

5160

5151

5152

5153
Urantum Concentration $\underbrace{(p p m=\mu g / g)}_{\text {Result }}$

1
3
23

0.5

0.4

0.6

1

1

0.9

0.7

2

1

0.4

0.5

0.9

0.4

0.3

0.3

0.3

0.3

0.3

0.5

0.5

0.3

0.5

0.8

0.2 
TABLE A-I I

ANALYTICAL RESULTS FOR EAFB SOIL SAMPLES COLLECTED FROM RANGE CLEANUP OPERATIONS DURING JUNE 1977

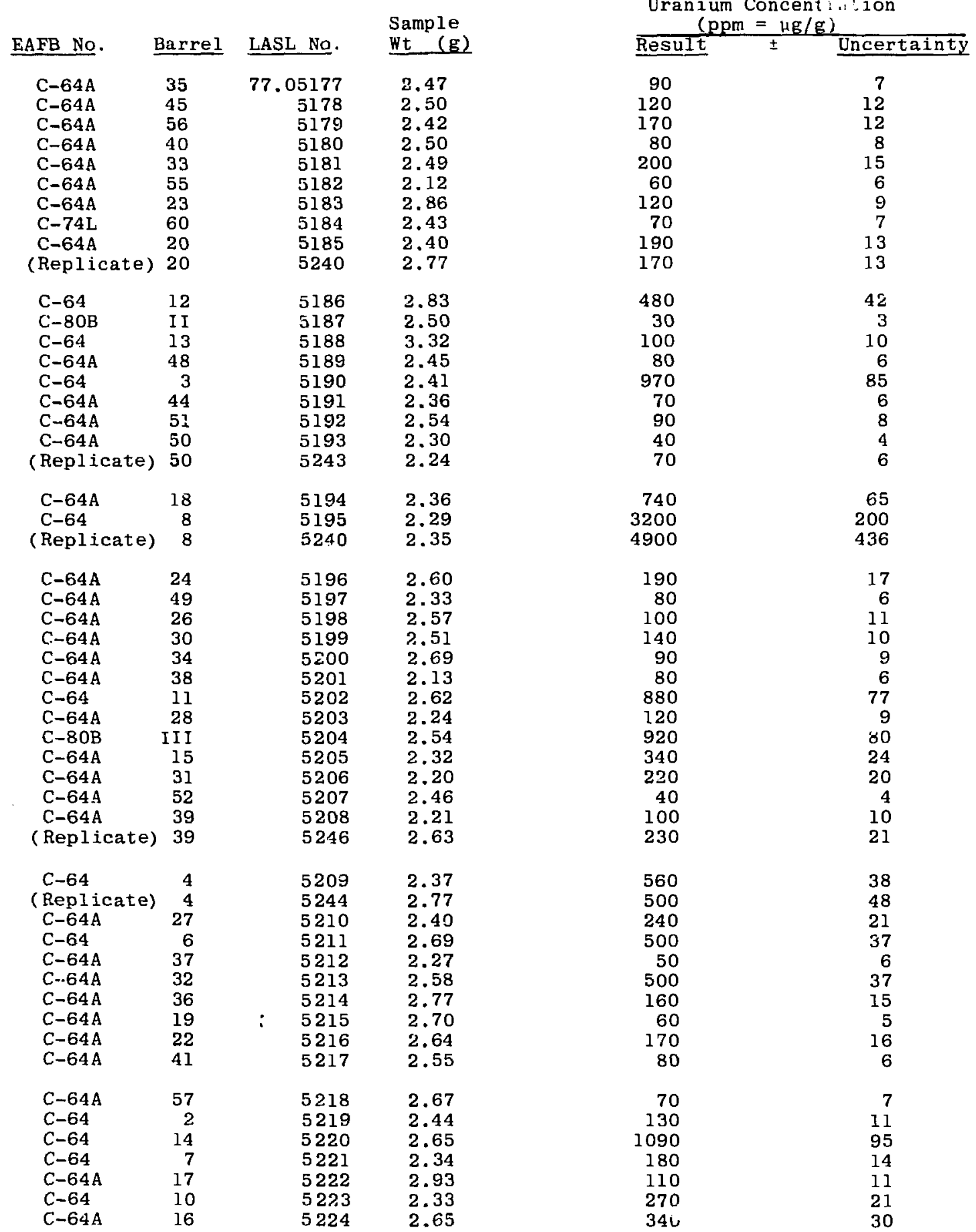


TABLE A-II (cont)

\begin{tabular}{|c|c|c|c|}
\hline EAFB No. & Barrel & LASL No. & $\begin{array}{l}\text { Sample } \\
\text { Wt (B) }\end{array}$ \\
\hline $\begin{array}{l}\text { C-64A } \\
\text { C-64A } \\
\text { (Replicate) }\end{array}$ & $\begin{array}{r}21 \\
54 \\
54\end{array}$ & $\begin{array}{r}77.05225 \\
5226 \\
5242\end{array}$ & $\begin{array}{l}2.81 \\
2.18 \\
2.19\end{array}$ \\
\hline $\begin{array}{l}C-64 \\
C-64 A \\
C-64 A \\
C-74 L \\
C-74 L \\
C-64 A \\
C-64 A \\
C-64 \\
C-64 A \\
C-64 A \\
C-64 A \\
C-64 A\end{array}$ & $\begin{array}{r}9 \\
46 \\
1 \\
59 \\
58 \\
43 \\
47 \\
5 \\
25 \\
53 \\
42 \\
29\end{array}$ & $\begin{array}{l}\mathbf{5 2 2 7} \\
\mathbf{5 2 2 8} \\
\mathbf{5 2 2 9} \\
\mathbf{5 2 3 0} \\
\mathbf{5 2 3 1} \\
\mathbf{5 2 3 2} \\
\mathbf{5 2 3 3} \\
\mathbf{5 2 3 4} \\
\mathbf{5 2 3 5} \\
\mathbf{5 2 3 6} \\
\mathbf{5 2 3 7} \\
\mathbf{5 2 3 8}\end{array}$ & $\begin{array}{l}2.58 \\
2.20 \\
2.30 \\
2.76 \\
2.47 \\
2.64 \\
2.48 \\
2.87 \\
2.58 \\
2.39 \\
2.35 \\
2.55\end{array}$ \\
\hline $\begin{array}{l}\text { Control } \\
\text { (Replicate) }\end{array}$ & ) & $\begin{array}{l}\mathbf{5 2 3 9} \\
\mathbf{5 2 4 5}\end{array}$ & $\begin{array}{l}3.00 \\
2.46\end{array}$ \\
\hline
\end{tabular}

Uranium Concentration
$\frac{(\mathrm{ppm}=\mu \mathrm{g} / \mathrm{g})}{\text { Result }} \pm$ Uncertainty

$\begin{array}{rr}100 & 8 \\ 120 & 11 \\ 100 & 10 \\ 230 & \\ 110 & 17 \\ 430 & 10 \\ 200 & 32 \\ 80 & 18 \\ 40 & 7 \\ 70 & 4 \\ 2030 & 6 \\ 220 & 176 \\ 170 & 17 \\ 80 & 16 \\ 220 & 7 \\ & 20\end{array}$

$\begin{array}{ll}1 & 1 \\ 0.6 & 2\end{array}$ 
TABLE A-I I I

ANALYTICAL RESULTS FOR EAFB SOIL SAMPLES COLLECTED

DURING THE PERIOD JUNE 14-17, 1977

EAFB No.

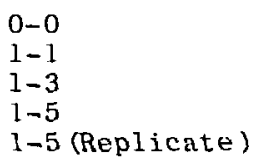

$1-7$

$1-9$

$1-11$

$1-13$

$1-15$

$1-17$

$2-0$

2-2

2-4

$2-6$

2-8

$2-10$

2-12

2-14

3-1

3-3

3-5

3-7

3-7 (Replicate)

3-9

3-11

3-13

$3-15$

3-17

3-17 (Replicate)

4-0

4-0 (Replicate)

4-2

4-4

$4-6$

4-8

$4-10$

4-12

$4-14$

5-1

$5-3$

5-3 (Replicate)

5-5

$5-7$

5-9

5-11

5-15

5-17

6-0

$6-2$

$6-4$

6-6

6-8

6-10

6-10 (Replicate)

$6-12$

$6-14$
LASL No.

77.06228

229

230

231

232

233

234

235

236

237

238

239

240

241

242

243

244

245

246

347

248

249

250

283

251

252

253

254

255

284

256

257

258

259

260

261

262

263

264

265

266

267

268

269

270

271

¿72

27

274

275

276

277

278

279

280

281

282
Sample

Wt (E)

2.33

2. 06

2.12

2,31

2.28

2. 27

2.44

1.94

2.21

2.14

2. 16

2.20

2.42

2.18

1.96

2.01

1.92

2.50

2.41

2.27

2. 06

2.13

2.30

2.46

2.09

2.19

2.25

2.11

2.09

2. 07

1.92

2.41

2. 36

2. 31

2.24

2.06

2.27

2. 38

2.27

2.35

2.17

2. 39

2. 09

2.20

1.98

2.11

2. 16

2.23

2.28

2. 26

2.40

2. 09

2.13

2. 22

2. 14

2. 32

2.31
Uranium Concentration

$\frac{\text { Result }}{(\mathrm{ppm}=\mu \mathrm{g} / \mathrm{g})} \underset{\text { Uncertainty }}{\text { Uncerta }}$

300
8.7
25
42
39

30

183

10

162

13.9

$<1.0$

46

75

21

9.4

4.5

3.2

2.2

8

3. 4

19

2.3

2.3

1.5

$<1.0$

3.2

2.6

10.6

1.7

1.4

3.2

3.5

3. 8

$<1.0$

$<1.0$

1.1

1.2

2.0

7.7

2.2

$<1.0$

1.3

$<1.0$

$<1.0$

$<1.0$

1. 1

6.4

1.0

1. 7

3. 4

1.7

$<1.0$

$<1.0$

$<1.0$

$<1.0$

$<1.0$

1.6
1.2

$$
3
$$$$
\begin{aligned}
& 4 \\
& 4
\end{aligned}
$$

19

1.3

16

1.7

5

8

1.3

0.9

0.8

0.9

1.4

0.9

2. 7

0.8

0.9

0.8

0.9

1. 4

0.8

0.7

0.7

0.8

0.8

0.7

0.7

0.7

1. 1

0.8

0.7

0.7

1.0

0.7

0.8

0.9

0.7

0.8 
